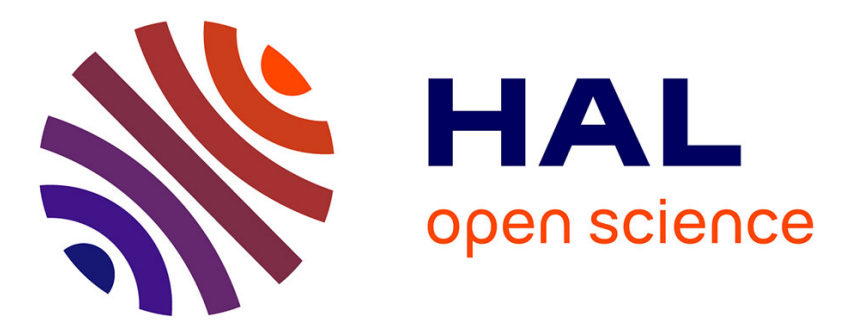

\title{
Uplift of Quaternary shorelines in Eastern Patagonia: Darwin revisited
}

Kevin Pedoja, Vincent Regard, Laurent Husson, Joseph Martinod, Benjamin Guillaume, Enrique Fucks, Maximiliano Iglesias, Pierre Weill

\section{To cite this version:}

Kevin Pedoja, Vincent Regard, Laurent Husson, Joseph Martinod, Benjamin Guillaume, et al.. Uplift of Quaternary shorelines in Eastern Patagonia: Darwin revisited. Geomorphology, 2011, 127 (3-4), pp.121-142. 10.1016/j.geomorph.2010.08.003 . insu-00610899

\section{HAL Id: insu-00610899 \\ https://hal-insu.archives-ouvertes.fr/insu-00610899}

Submitted on 6 Mar 2019

HAL is a multi-disciplinary open access archive for the deposit and dissemination of scientific research documents, whether they are published or not. The documents may come from teaching and research institutions in France or abroad, or from public or private research centers.
L'archive ouverte pluridisciplinaire HAL, est destinée au dépôt et à la diffusion de documents scientifiques de niveau recherche, publiés ou non, émanant des établissements d'enseignement et de recherche français ou étrangers, des laboratoires publics ou privés.

\section{(c)(1)}

Distributed under a Creative Commons Attribution| 4.0 International License 


\title{
Uplift of quaternary shorelines in eastern Patagonia: Darwin revisited
}

\author{
Kevin Pedoja ${ }^{\mathrm{a}, *}$, Vincent Regard ${ }^{\text {b,c,d }}$, Laurent Husson ${ }^{\mathrm{e}, \mathrm{f}}$, Joseph Martinod ${ }^{\text {b,c,d }}$, Benjamin Guillaume ${ }^{\mathrm{g}}$, \\ Enrique Fucks ${ }^{\mathrm{h}}$, Maximiliano Iglesias ${ }^{\mathrm{i}}$, Pierre Weill ${ }^{\mathrm{a}}$ \\ a Laboratoire de Morphodynamique Continentale et Côtière, CNRS, Université de Caen, 14000 Caen, France \\ ${ }^{\mathrm{b}}$ Université de Toulouse ; UPS (OMP) ; LMTG ; 14 Av Edouard Belin, F-31400 Toulouse, France \\ ${ }^{c}$ IRD ; LMTG ; F-31400 Toulouse, France \\ ${ }^{\mathrm{d}}$ CNRS ; LMTG ; F-31400 Toulouse, France \\ e CNRS UMR 6118, Géosciences Rennes, 35042 Rennes, France \\ ${ }^{\mathrm{f}}$ CNRS UMR 6112, Laboratoire de Planétologie et Géodynamique de Nantes, France \\ ${ }^{g}$ Dip. di Scienze Geologiche, Università Roma Tre; CNR, 00146 Roma, Italy \\ h Catedra de Geologia del Cauternario y Geomorfologia, Universidad. Nacional de La Plata, Argentina \\ ${ }^{\text {i } U n i v e r s i d a d ~ N a c i o n a l ~ d e ~ l a ~ P a t a g o n i a ~ S a n ~ J u a n ~ B o s c o, ~ C o m o d o r o ~ R i v a d a v i a, ~ A r g e n t i n a ~}$
}

\begin{abstract}
During his journey on the Beagle, Darwin observed the uniformity in the elevation of coastal Eastern Patagonia along more than $2000 \mathrm{~km}$. More than one century later, the sequences of Quaternary shorelines of eastern Patagonia have been described and their deposits dated but not yet interpreted in terms of geodynamics. Consequently, we i) mapped the repartition of the Quaternary coastal sequences in Argentinean Patagonia, ii) secured accurate altitudes of shoreline angles associated with erosional morphologies (i.e. marine terraces and notches), iii) took into account previous chrono-stratigraphical interpretations in order to calculate mean uplift rates since $440 \mathrm{ka}$ (MIS 11) and proposed age ranges for the higher and older features (up to $180 \mathrm{~m}$ ), and iv) focused on the Last Interglacial Maximum terrace (MIS $5 e$ ) as the best constrained marine terrace (in terms of age and altitude) in order to use it as a tectonic benchmark to quantify uplift rates along the entire passive margin of Eastern South America. Our results show that the eastern Patagonia uplift is constant through time and twice the uplift of the rest of the South American margin. We suggest that the enhanced uplift along the eastern Patagonian coast that interested Darwin during his journey around South America on the Beagle could originate from the subduction of the Chile ridge and the associated dynamic uplift.
\end{abstract}

\section{Introduction}

Quaternary raised coastal morphologies and deposits in eastern Patagonia and Tierra del Fuego have long been a scientific curiosity, first described with respect to their paleontology during the middle of the nineteenth century (d'Orbigny, 1834-1847). Darwin (1846) visited the sequence of fossil shorelines of eastern Patagonia and provided the first regional stratigraphic description. About a century later, Feruglio $(1933,1950)$ presented the first comprehensive description and concluded that the marine origin of the terraces described by Darwin (especially the highest) was not fully proven due to some confusion with alluvial or structural terraces. For the last 25 years, studies focused on dating and correlating the terraces (Codignotto, 1983; Rutter et al., 1989, 1990; Codignotto et al., 1992; Schellmann and Radtke, 1997, 2000, 2003), describing Holocene coastal development (González Bonorino et al., 1999; Vilas et al.,

\footnotetext{
* Corresponding author.

E-mail address: Francekevin.pedoja@unicaen.fr (K. Pedoja).
}

1999), determining paleoenvironments through malacofaunal studies (Aguirre, 2003; Aguirre et al., 2005, 2006, 2009) and pedology (Sauer et al., 2007).

Surprisingly, there is still very little accurate information on the number, age, characteristics, geomorphology and geographical development of the Quaternary shorelines. With a few exceptions (Codignotto et al., 1992; Rostami et al., 2000), no effort has been made to use these features as tectonic indicators. Even if Late Pleistocene (i.e. Marine Isotopic Stage, MIS 5e) and Holocene coastal deposits are well documented, the older levels are poorly constrained both in time and space (i.e. number of terrace levels, elevations, etc.). For example, the occurrence of marine terraces that relate to the isotopic stage MIS 7 is debated (e.g. Zazo, 1999).

Our goals are to i) map the repartition of the Quaternary coastal sequences in Argentinean Patagonia, ii) secure accurate altitudes of shoreline angles associated with erosional morphologies (i.e. marine terraces and notches) iii) take into account previous chronostratigraphical interpretations, calculating mean uplift rates since $\sim 440 \mathrm{ka}$ (MIS 11) and proposing age ranges for the higher and older features (up to $\sim 180 \mathrm{~m}$ ), and iv) focus on Last Interglacial Maximum 
terrace (MIS 5e) as the best constrained marine terrace (in term of age and altitude) in order to use it as a tectonic benchmark to quantify uplift rates along the entire passive margin of Eastern South America. In this respect, uplift is interpreted as a geodynamic indicator.

\section{Settings}

\subsection{Geodynamics and geology}

The Atlantic coast of Patagonia is located within a broad continental platform that spans from the Southern tip of the Andes to the west, to the Atlantic margin. The South American continental shelf is more than $400 \mathrm{~km}$-wide offshore Patagonia and expands to the Malvinas (Falkland) Islands to the east.

Patagonia accreted to Gondwana in the Late Paleozoic (Permian) (Ramos, 1996). Oceanic subduction below western Patagonia has been active since at least the beginning of Middle Jurassic (Ramos, 1981, 2002) and perhaps earlier (Rapalini et al., 2001; Hervé et al., 2007). Following Permian accretion, Patagonia recorded an episode of continental extension that started in the upper Triassic and continued during the Lower and Middle Jurassic (Ramos, 2002). A major extension event resulted from the rupture of Gondwana, and seafloor spreading started $132 \mathrm{Ma}$ ago (Torsvik et al., 2009). The separation between the Antarctic and South American plates occurred later during Paleogene, and sea-floor spreading in the Western Scotia plate initiated in the Oligocene 30 Ma ago (Cunningham et al., 1995; Barker, 2001).

The opening of the Atlantic Ocean triggered the westward drift of South America in the hot spot reference frame, which in turn resulted in E-W shortening along the western margin of South America (e.g. Silver et al., 1998). The Andean orogenesis has been affected by the interaction with spreading ridges. In particular, from 14 Ma onwards, the Chile ridge that separates the Nazca plate from the Antarctic plate joined the subduction trench west of Patagonia. The associated triple junction was located close to the straight of Magallanes $14 \mathrm{Ma}$ ago (Cande and Leslie, 1986), and migrated northward to its present-day location offshore the Taitao Peninsula $\left(46^{\circ} 15^{\prime} \mathrm{S}\right)$.

\subsubsection{Present-day geodynamics and geological setting}

North of the Chile Triple Junction, the Nazca plate is subducting below South America at $78 \mathrm{~mm} / \mathrm{yr}$, while below southern Patagonia, the Antarctic plate subducts at a much slower velocity $(\sim 20 \mathrm{~mm} / \mathrm{yr})$ (DeMets et al., 1994). South-east of the Tierra del Fuego, the Scotia plate moves eastward at a rate of $\sim 70 \mathrm{~mm} / \mathrm{yr}$ with respect to South America (Thomas et al., 2003).

The interaction of the Chile ridge with the subduction trench opened a new asthenospheric window below southern Patagonia that modified mantle flow (e.g. Ramos and Kay, 1992; Guivel et al., 2003; Guillaume et al., 2009). This slab window triggered a new widespread episode of back-arc magmatism in southern Patagonia. Plateau-lavas related to the opening of this slab window seal the eastern thrust front of the Patagonian Andes, implying that the compressive tectonic activity in the Andes of Southern Patagonia essentially ended before Late Miocene (Ramos, 1989; Coutand et al., 1999; Lagabrielle et al., 2004, 2007).

Guillaume et al. (2009) argue that the opening of the slab window also resulted in a long-wavelength $(>1000 \mathrm{~km})$ dynamic uplift of Southern Patagonia. Models simulating the mantle dynamics associated with the subduction of an oceanic plate, indeed, predict that the topography of the plate overriding an oceanic subduction zone may be deflected by more than $1000 \mathrm{~m}$ by the descending motion of the slab (e.g. Mitrovica et al., 1989; Gurnis, 1993; Husson, 2006). The opening of the slab window cancels this downward deflection, resulting in the uplift of the continental plate. This uplift results in the generalized erosion of the Andean forearc since the Late Miocene. It is responsible for the tilting of the fluvial terraces of the Río Senguerr and Río Deseado valleys $\left(45-48^{\circ} \mathrm{S}\right)$ (Guillaume et al., 2009). Although corresponding rates are probably small, this uplift may also be observed in marine terraces: numerical models, indeed, predict a total uplift approaching $400 \mathrm{~m}$ since the Late Miocene along the Atlantic Coast of Southern Patagonia.

Patagonian Andes are also the locus of the largest ice-fields in the Southern hemisphere outside of Antarctica. Basaltic flows interbedded within tills give a $\sim 6 \mathrm{Ma}$-old age for some glacial deposits, implying glaciations may be as old as Late Miocene in the Patagonian Andes (Ton-That et al., 1999). Most of the Andean foreland, however, remained ice-free and glaciers only reached the Atlantic coast close to the Strait of Magallanes and in Tierra del Fuego. During cold periods, the Patagonian ice-cap fills valleys in the Cordillera, reinforcing the eastward migration of rivers descending the Andes (Feruglio, 1950; Mercer, 1976; Turner et al., 2005). The maximum volume of the ice-cap covering Southern Andes may have reached $5 \times 10^{5} \mathrm{~km}^{3}$, capable, of causing equivalent sea level rise of about $1.2 \mathrm{~m}$ upon melting (Hulton et al., 2002). The maximum ice volume during the last glacial period, estimated to be $70 \mathrm{kyr}$-old, has been somewhat smaller $\left(\sim 3.5 \times 10^{5} \mathrm{~km}^{3}\right)$. The ice-load has been estimated using dated moraines and dynamic ice sheet modeling. Glacioisostatic rebound models suggest small present-day vertical motions on the Atlantic coast of Patagonia north of $50^{\circ} \mathrm{S}$ (Ivins and James, 2004; Klemann et al., 2007).

Rostami et al. (2000) observed, however, that Holocene $\sim 7$ kyr-old marine terraces are $0-1 \mathrm{~m}$ amsl in Brazil, $\sim 6 \mathrm{~m}$ amsl in Northern Patagonia, and $~ 7-8 \mathrm{~m}$ amsl in the Southern Patagonia Atlantic coasts. These authors note that glacial isostatic models do not explain the large amount of uplift registered in Patagonia for 7000 years, and that other geodynamic processes may be responsible for part of this uplift.

\subsection{Previous studies on coastal deposits and morphologies}

During his journey on the Beagle, Darwin took an interest in "the elevation of the land within the recent period, and the modification of its surface through the action of the sea" (Darwin, 1846). In particular, he observed the uniformity in the elevation of coastal Eastern Patagonia along more than $2000 \mathrm{~km}$ and he described the uniformity of four great terraces that often rise like steps, one behind the other, that he attributed to the coastal denudation of older Patagonian Tertiary beds, and the subsequent deposition of a mass of well-rounded gravel. Darwin (1846) observed the occurrence of shells on terraces at various elevations, which he explained by large-scale uplift. He was especially impressed by the remarkable degree of equability in this elevatory process over a $2000 \mathrm{~km}$ stretch of coastline.

The first complete descriptions of the morphology, lithology, paleontology and relative chronology of the Quaternary marine terraces in eastern Patagonia were consequently completed by Feruglio (1933, 1950). This author described many fossiliferous deposits (55 sites) and proposed a general stratigraphy: a "synthetic" sequence of six fossil marine deposits, ranging from approximately 8 to $186 \mathrm{~m}$ above mean sea level (amsl). As Darwin (1846) before him, Feruglio (1950) found these terraces in the same narrow range of elevations at widely separated locations along the coast. The latter attributed emergence of the Patagonian marine sequences to the process of marginal uplift. In terms of age control, the first radiocarbon ages of mollusc shells sampled from the Eastern Patagonian coastal deposits were provided by Codignotto (1983). Soon afterwards, Rutter et al. (1989, 1990) provided aminostratigraphy and Electron Spin Resonance (ESR) dating from some locations. Their ESR results yielded Last Interglacial ages (MIS 5e) for most of the locations, whereas ages obtained on the basis of aminostratigraphy suggested penultimate interglacial (MIS 7) or older deposits. ESR and U/Th dating by Radtke (1989) showed that Holocene beaches sit at higher elevation in the South of Patagonia than in the North. Schellmann and Radtke (1997) 
and Schellmann (1998a,b), reported ESR ages belonging to Marine Isotopic Stages 5, 7 and 9 for some sites along eastern Patagonia.

Previous studies rely on various kinds of dating method including ${ }^{14} \mathrm{C}, \mathrm{U} / \mathrm{Th}$, ESR and amino acid racemization. For clarity sake, we quickly review hereafter the basics and the uncertainties of each dating method. In fact, the accuracy of dating must be sufficient to discriminate between the different Marine Isotopic Stages, separated by $\sim 100 \mathrm{kyr}$. Sometimes the data requires improved resolution, allowing for discriminating between substages ( $20 \mathrm{kyr})$, as between MIS $5 \mathrm{c}$ (100 kyr) and MIS 5e (125 kyr). We do not consider the ${ }^{14} \mathrm{C}$ method here because it is of use only for recent deposits, i.e. Holocene. The U/Th method is based on the ratio between ${ }^{234} \mathrm{U}$ and ${ }^{230} \mathrm{Th}$. Contrarily to Th, $\mathrm{U}$ is soluble in water, thus molluscs or corals incorporate $U$ in the calcite they precipitate. At deposition time, it is assumed that there is no Th; it then accumulates after the disintegration of ${ }^{234} U$ (half-life is $245 \mathrm{ka}$ ). Th is itself radioactive (half-life of $75 \mathrm{ka}$ ), which bounds the method, depending to the resolution of the technique (approx. $>250 \mathrm{ka}$ for alpha-spectrometry, $>350$ ka for TIMS) (Ludwig, 2003). It has a good accuracy in corals which are U-rich, but it is less accurate in shells which incorporate much less $U$. The U/Th samples reported in this paper are processed from shells; the typical uncertainties are reported in Table 1. ESR dating is based on the ability of the carbonate lattice to store radioactive energy (Zeller et al., 1967). Constant exposure of the material to ionizing radiation resulting from the decay of $\mathrm{U}$, Th and $\mathrm{K}$ in the surrounding sediment produces free electrons in the carbonate, of which a certain number are trapped at impurity sites in the lattice (Barabas et al., 1992a,b). As the number of trapped electrons increases with time and as, during the mineralization of the carbonate, no radicals were present (i.e., zero ESR signal), the intensity of the ESR signal measured today is correlated to the age of the sample. Dating results become less precise with increasing age (cf. Table 1). Amino acids from biological tissues possess an asymmetric carbon atom (except glycine), which means that the amino acid can have two different configurations, "D" or "L". Living organisms usually keep all their amino acids in the " $\mathrm{L}$ " configuration. When an organism dies, control over the configuration of the amino acids ceases, and the ratio of $\mathrm{D} / \mathrm{L}$ moves slowly toward equilibrium. Thus, the ratio of $\mathrm{D} / \mathrm{L}$ of a sample can be used as a proxy for the time at which the specimen died. Different amino acid can be used. We report isoleucine results, allowing for dating between $5 \mathrm{kyr}$ and 2Myr. In fact, this dating is not precise and is more suited for correlation to an interglacial, not to substages (see Rutter et al., 1989).

In short, previous studies have focused on the dating of deposits from beach ridges sequences. The low uplift rate of the area resulted in frequent cannibalization of some deposits by more recent ones (e.g. Rostami et al., 2000). Dating was mostly concentrated on the Holocene (data on all zones, Fig. 1A) and MIS 5e (last interglacial, data on zones 1, 2, 3, 4, 5, 7, Fig. 1A). Deposits from older terraces have been dated and tentatively correlated to MIS 7, 9 and 11 in some zones. A major problem persists however, in the question of whether or not there exists any marine terraces correlated to MIS 7. For example, in Bahía Bustamante at least two beach ridges have been correlated to MIS 7 (Schellmann and Radtke, 2000; Aguirre et al., 2005) whereas Rostami et al. (2000) proposed that MIS 7 was i) reoccupied by the MIS 5e terrace, ii) lower than the MIS 5e terrace (i.e. their respective elevations are $\sim 11 \mathrm{~m}$ for MIS 7 and $17 \mathrm{~m}$ for MIS 5e). It must be emphasized that all these authors focused on depositional morphologies (i.e. beach ridges) and not on erosional ones.
Previous estimates of tectonic uplift of coastal Eastern Patagonia are scarce. Rostami et al. (2000) considered that the Eemian (i.e. Last Interglacial) paleoshorelines found at $16-17 \mathrm{~m}$ amsl were tectonically uplifted by approximately $10 \mathrm{~m}$. In other words they consider that the sea level during Last Interglacial was 6-7 m higher than nowadays. These authors used their data to compute a regional tectonic uplift rate of $0.09 \pm 0.02 \mathrm{~mm} / \mathrm{yr}$. They concluded that: i) terraces of the same age are found at approximately the same elevation, ii) molluscbearing horizons deposited at approximately 300 ka have now risen to 33-35 m, iii) paleoshorelines formed during MIS 7 are absent. They explained this absence by re-occupation during MIS $5 \mathrm{e}$.

\section{Materials and method}

Our contribution concentrates on the establishment of a geographical and altitudinal description of coastal Quaternary morphologies and, more particularly, on the description of erosional morphologies. In order to focus on the large-scale uplift of Patagonia in its geodynamic framework, we decided to perform a large-scale survey of the morphology of Atlantic coast of Patagonia, and to calibrate the timing of our observations on previously documented sites. The advantage of such a strategy is that it allows for the emergence of the big picture, the drawback is that it relies on previous works and requires interpolation. Such a choice is nevertheless certainly reasonable along passive margins, because the processes that make uplift rates vary laterally most likely relate to the dynamics of mantle flow and, therefore, will be chiefly low frequencies. Therefore we believe we had enough calibration points from previous works and that our choice made possible a global analysis of the coast of Patagonia within its geodynamic framework, something that has never properly been achieved before.

\subsection{Morphologies}

It is now widely accepted that coastal sequences are formed during the separate highstands of interglacial stages correlated to uneven Marine Isotopic Stages (MIS) (e.g. James et al., 1971; Chappell, 1974; Bull, 1985; Lajoie, 1986). On the Argentinean coast of Patagonia, uplift is both recorded by depositional or erosional coastal sequences. Lateral changes in facies are sometimes extremely rapid from one morphology to another (see for example San Julian).

\subsubsection{Erosional morphologies: marine terraces and notches}

On steadily uplifting coasts, marine terrace sequences are represented by flights of "stairs" up to hundreds of meters in altitude above mean sea level. Each terrace corresponds to a gently seawarddipping erosional platform backed by a relict sea cliff. The shoreline angle or inner edge of the terrace (i.e. intersection of the relict platform and the relict sea cliff) provides a good approximation of the location and elevation of a former shoreline and hence, a marker for relative sea level (e.g. Bull, 1985). Uplift can also be registered through sequences of notches that are visible as horizontal incisions in the cliffs. Their widths and excavation depths may reach a few meters. Notches are often portrayed as forming at sea level; however notch types actually reflect a continuum from wave notches formed under quiet conditions at sea level to surf notches formed under more turbulent conditions and as much as $2 \mathrm{~m}$ above sea level (Pirazzoli,

Table 1

Typical uncertainties of U/Th and ESR dating methods.

\begin{tabular}{|c|c|c|c|c|c|}
\hline & $10 \mathrm{ka}$ & $100 \mathrm{ka}$ & $200 \mathrm{ka}$ & $300 \mathrm{ka}$ & Ref \\
\hline U/Th, Alpha spectrometer & $2 \mathrm{ka}$ & $5-10 \mathrm{ka}$ & 20-30 ka & $30-50 \mathrm{ka}$ & (Rostami et al., 2000; Schellmann and Radtke, 2000) \\
\hline U/Th, TIMS & & $3-5$ ka & & & Rostami et al. (2000) \\
\hline ESR & & $10-20 \mathrm{ka}$ & $20-40 \mathrm{ka}$ & $30-100 \mathrm{ka}$ & (Rutter et al., 1990; Rostami et al., 2000; Schellmann and Radtke, 2000) \\
\hline
\end{tabular}




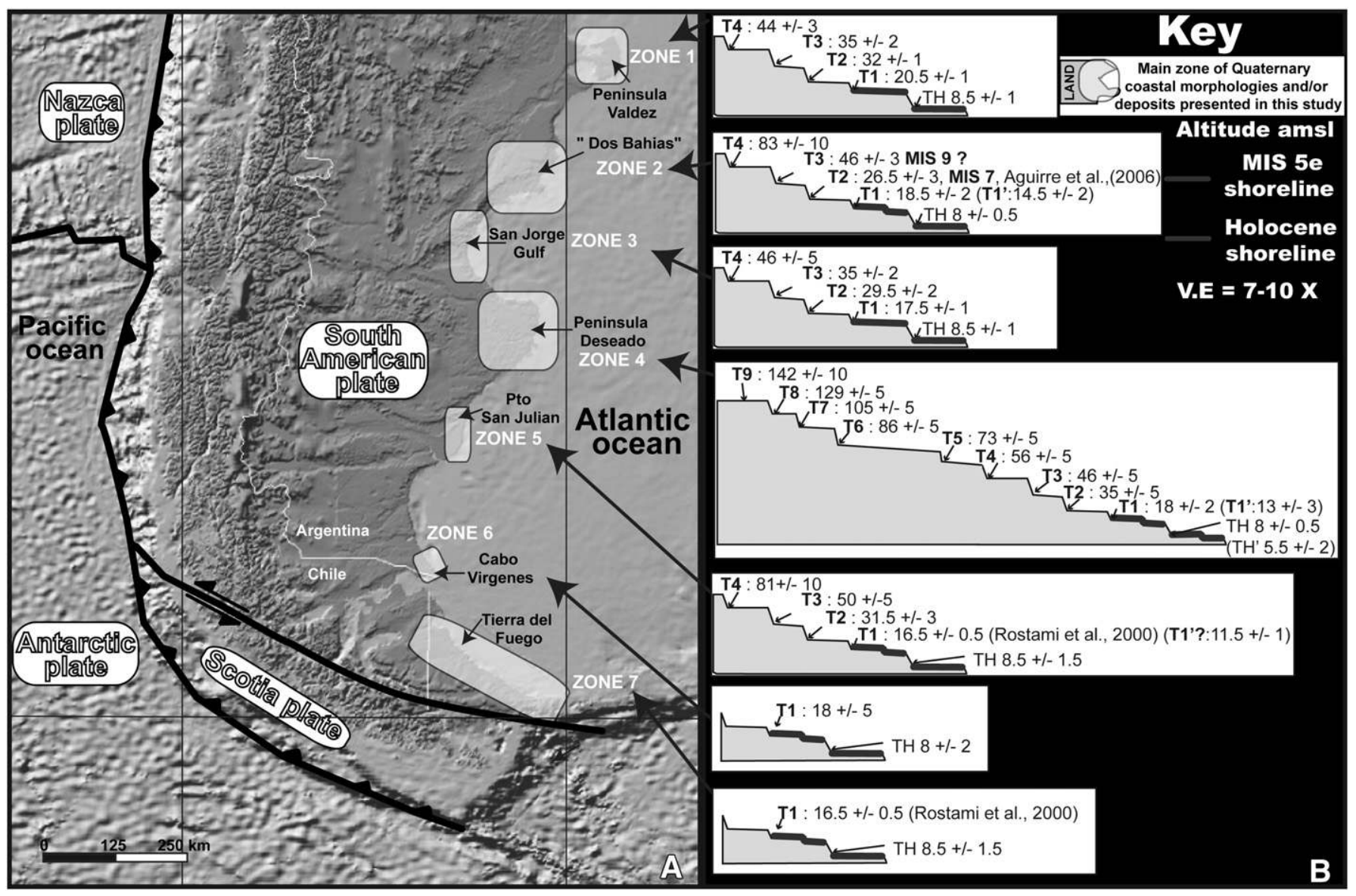

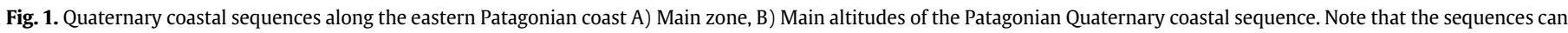
be composites.

1996). Notches are particularly well documented for the Holocene (e.g. Cooper et al., 2007) but few data are known from the Pleistocene (e.g. Maeda et al., 2004).

\subsubsection{Depositional morphologies: wave-built terrace, beach ridges} and cheniers

Wave-built terraces develop near sea level and are made of accumulations of marine materials removed by shore erosion. Depositional shore platforms produced by the supply of marine sediments (sand, gravel, or shells) to the shore have been described in the Crescent City coastal plain (USA) by Polenz and Kelsey (1999); coastal plains characterized by many shelly ridges that run roughly parallel to the shore, in northeast gulf of Mexico (Otvos, 1981).

A variety of views on the formation and preservation conditions of beach ridges has been expressed regarding modes of beach ridge construction (during high or low wave energy, during bar welding, by swash action, by sea level change, or by aeolian processes; e.g. Sanjaume and Tolgensbakk, 2009). The lack of abundant sediment supply is an obstacle to the formation of beach ridge plains. Arguments supporting the formation of beach ridges during high wave energy appear convincing where coarse clastic beaches enhance percolation rates leading to deposition at the limit of wave run-up (e.g. Otvos, 2000). The spacing between beach ridges is reported to indicate the recurrence of the triggering processes (storm, sea level variations, and sediment availability; Isla and Bujalesky, 2000). The most common interval for constructing a single swash-built sand beach is $30-60$ years (Tanner, 1995a,b).

Found in more sheltered areas, such as indented bays and estuaries, chenier ridges are transgressive beach ridges that become isolated from the shore by a band of prograding mudflats (Otvos and
Price, 1979). They result from a balance between fine-grained sediment source, derived from fluvial or tidal dynamics (mudflat progradation), and coarse-grained sediment supplied and piled up by wave action. Mainly composed of shell debris, cheniers provide material for accurate dating, which can be used to determine the lateral continuity between other depositional (gravel beach ridges) or erosional morphologies. These features are common in Holocene coastal plains (Augustinus, 1989), but have rarely been described in older Quaternary deposits. Meldahl (1995) describes chenier ridges in the northern Gulf of California formed during Pleistocene highstands, and more especially during MIS 5e. Other Pleistocene cheniers are suspected to be present in Bahía San Sebastian (Argentina), or in the northeastern part of the gulf of Mexico. The lack of description of cheniers prior to Holocene deposits is probably due to confusion with beach ridge sequences, and a lack of sub-surface and stratigraphic information (Hoyt, 1969).

\subsection{Mapping, altimetry}

Our principal method consists in the mapping of Late Quaternary paleoshorelines and the determination of the paleo rocky-shore elevation above mean sea level in order to calculate uplift rates. Quaternary shoreline mapping was accomplished through field studies complemented by observations on Google Earth and/or GeomapApp.

Conventionally, the shoreline at any given location and any given time is the line of intersection of mean tide level at that time and the terrestrial surface at the given location. This line corresponds generally to the line joining points located at the high-water mark during ordinary spring tides (Wright, 1970; Jardine, 1981). Called the shoreline angle, this morphology is painstakingly measured in studies 
of shoreline changes. In practice, however, the line that is plotted as the former shoreline is the position of a break in slope distinguishable in the field (e.g. Jardine, 1981), but breaks in slope occur in a variety of forms. The majority may be included within one or another of five major categories defined by Jardine (1981) for other areas of large tidal range (i.e. Scotland): 1) junction between steep cliffs in solid rock and either rock platform or shore sediments, 2) junction between terrestrial (including deltaic and fluvioglacial) sedimentary bodies and shore sediments, 3) junctions between "normal" shore sediments and storm debris, 4) low cliffs within former shore sediments and 5) bases of areas of accentuated slope within "normal" shore sediments. In eastern Patagonia the major breaks in slope belong to the 1st, 3rd, 4 th and 5th categories.

In previous studies, the criteria used in the field for determination of the position of former shorelines are not always stated or discussed, although it is particularly important in eastern Patagonia where the tidal range is large. Approximate elevations of these features originally quoted by Feruglio (1950) were most probably obtained from topographic maps and it appears that most of the later investigators simply adopted the same elevations.

In a broad sense, the nature of the measured break in slope is responsible for the discrepancy in altitude observed between paleosedimentary shores and paleo-rocky shores. Because our study concentrates on rocky shores, the majority of the measurements were performed at the junction between cliffs in solid rock and either rock platform or shore sediments. Nevertheless, on modern rockyshores, the break in slope of such morphologies is known to exhibit pluri-metric variations (Wright, 1970) that depend on the wave action and tidal range.

In order to avoid the uncertainty issue relative to the initial elevation of a paleoshoreline (a few meters above or below the current sea level), it is desirable to measure the elevation of a fossil shoreline with respect to the same current shore morphology, not the current sea level (Pirazzoli, 1996). Unfortunately, this practice is difficult to apply in eastern Patagonia chiefly because dual observations of comparable past and present-day shorelines are commonly difficult to achieve.

We measured the altitude of paleoshorelines with two altimeters (Alpinel, Garmin etrex vista). A Bushnell Legend 1200 ARC distance meter with clinometer was used to evaluate the width and elevation of the terraces. When possible we repeated the measurements (i.e. same place or nearby site of the same shoreline angle). We assigned a margin of error to every measurement. The error range mostly depends on the conservation and nature of the morphology corresponding to the paleoshoreline. In some places (e.g. Camarones, zone 2) we also performed altitudinal transects with a GPS. Our elevation measurements were corrected to local mean sea level by interpolation using the published tide tables for locations within the study area (Armada Argentina Servicio de Hidrographica Naval, 2008; http://www.hidro.gov.ar/oceanografia/Tmareas/Form_Tmareas.asp). Consequently, all altitudes are given above mean sea level (amsl).

\subsection{Uplift rate determination}

As stated above, the shoreline angle of a marine terrace represents the maximum extension of a transgression and, therefore, a highstand in former sea level. Displacement of the shoreline relative to the age of the associated interglacial stage yields a mean uplift rate.

The best-represented terrace worldwide is the one correlated to the last interglacial maximum (MIS 5e) (Hearty and Kindler, 1995; Johnson and Libbey, 1997; Pedoja et al., 2006a,b). The age of MIS 5e is arbitrarily fixed to range from 130 to 116 ka (Kukla et al., 2002) but compilations converge on a highstand lasting from $128 \pm 1 \mathrm{ka}$ BP to $116 \pm 1$ ka BP (e.g. Stirling et al., 1998) with sea levels around +2 to +4 m (e.g. Hearty and Kindler, 1995; Stirling et al., 1998; Schellmann and Radtke, 2004). Consequently we use an age of $122 \pm 6 \mathrm{ka}$ and discuss the impact of a possible sea level higher than the modern one by $3 \pm 1 \mathrm{~m}$.

Older marine terraces present in worldwide sequences are those related to MIS 7, 9 and 11 (e.g. Imbrie et al., 1984). Compilations show that the uncertainties are large in estimates of past interglacial sea level (e.g. Siddal et al., 2006). In this study, We considered that: i) polyphased MIS 7 lasted from 230 to $190 \mathrm{ka}$ (i.e. $210 \pm 20 \mathrm{ka}$ ) and that the sea level was $-1 \pm 1 \mathrm{~m}$ lower than today (Hearty and Kindler, 1995; Zazo, 1999) ii) MIS 9 lasted from 330 to $310 \mathrm{ka}$ (i.e. $320 \pm 10 \mathrm{ka}$ ) and that the sea level was $3 \pm 3 \mathrm{~m}$ above the modern one, and iii) MIS 11 lasted from 420 to $380 \mathrm{ka}$ (i.e. $400 \pm 20 \mathrm{ka}$ ) and that the sea level was $3 \pm 3 \mathrm{~m}$ above the modern one.

Our vertical rates for uplift $(\mathrm{V})$ are given by $\mathrm{V}=(\mathrm{E}-\mathrm{e}) / \mathrm{A}$ (e.g. Lajoie, 1986), where $\mathrm{E}$ is the current elevation of the paleoshoreline relative to current local sea level, $A$ is the age of the interglacial that created the morphology, and e is the correction for eustasy (elevation of the paleo-sea level relative to the modern one).

\subsection{Data compilation}

In order to consistently map the uplift rate along the entire eastern coast of South America, we synthesized previously published data on MIS 5e paleoshorelines. The data is compiled in a table that includes the location and elevation of MIS 5e paleoshorelines. Out of 40 published references, we recognize 33 sites. The table includes 16 columns listing the location (province, continent, ocean, and country), the morphologies (marine terraces, notch) or deposits (beach ridge, beach-rock, and coastal deposits), their altitudes and associated margin of error, the implied average vertical rate since MIS $5 \mathrm{e}$, the duration of uplift, the references and the degree of confidence in the data. In this compilation, we systematically attributed a minimum error range of $1 \mathrm{~m}$ to the measurements on altitude published without a margin of error. Where authors provided altitude range, we took the mean value of the range. For example, with a $20-30-\mathrm{m}$ high shoreline angle, $\mathrm{E}=25 \pm 5 \mathrm{~m}$. Where authors only correlate the paleocoast to MIS 5 (i.e. undifferentiated $5 \mathrm{a}, \mathrm{c}$, and e) we made the assumption that it correlates to MIS 5e-for it is the main marker of MIS 5-which gives the minimum uplift rate. The degree of confidence is noted on a scale of 1 to 5 : the higher the value, the better the data. The confidence score is primarily based on subjective estimates of the quality of dating, precision in measurements of altitudes, geographical descriptions.

\section{Results}

Along $1200 \mathrm{~km}$ of the eastern Patagonian and Fuegian coasts, Quaternary coastal morphologies and deposits are present in seven zones (Fig. 1), which are from north to south: 1) Peninsula Valdez, 2) "Dos Bahías" i.e. Bahía Camarones and Bahía Bustamante, 3) San Jorge Gulf, 4) Peninsula "Deseado", 5) San Julian, 6) South of Santa Cruz, Cabo Virgenes, and 7) Tierra del Fuego. We searched for marine terraces, notches and beach ridges sequences in zones 1-6 and collected 100 measurements for altitude of "shoreline angles" (for a synthesis for each zone see Fig. 1B and Table 2). In order to make a geographically consistent map, we included a short bibliographical synthesis on coastal sequences from Tierra del Fuego (Zone 7).

In the following, we only present extensively the sites that are poorly or not described in previous studies. Information about previously documented sites (e.g. Bahia Camarones) is given in Table 1. Expanded site descriptions are available as supplementary data.

\subsection{Site description}

\subsubsection{Zone 1: Peninsula Valdez}

Peninsula Valdez, a wide peninsula $(100 \times 70 \mathrm{~km})$ is located on the northern coast of Patagonia (Fig. 1). On the easternmost side of the Peninsula, in Caleta Valdez, a beach ridge and/or wave-built terrace 
Table 2

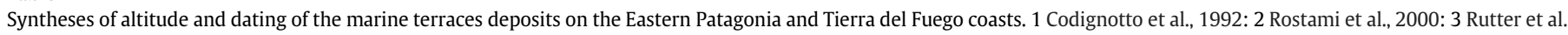
1989: 4 Schellmann and Radtke, 2003: 5 Schellmann and Radtke, 2000: 6 Schellmann, 1998: 7 Schellmann and Radtke, $1997: 8$ Aguirre et al., 2006.

\begin{tabular}{|c|c|c|c|c|c|c|c|c|c|c|c|c|c|c|}
\hline \multirow[t]{2}{*}{ Zone } & \multirow[t]{2}{*}{ Area } & \multirow[t]{2}{*}{ Site } & \multicolumn{4}{|l|}{$\mathrm{TH}$} & \multicolumn{4}{|l|}{$\mathrm{T} 1$} & \multicolumn{4}{|l|}{$\mathrm{T} 2$} \\
\hline & & & $\mathrm{E}$ & MoE & Dating & $\mathrm{CS}$ & $\mathrm{E}$ & $\mathrm{MoE}$ & Dating & CS & $\mathrm{E}$ & $\mathrm{MoE}$ & Dating & CS \\
\hline \multirow[t]{3}{*}{1} & Pto Piramide & Pto Piramide & $*$ & $*$ & & $*$ & 20 & 5 & & MIS 5e & 29 & 5 & & MIS 7 \\
\hline & Caleta Valdez & North & 8.5 & 1 & $\mathrm{C} 14, \mathrm{U} / \mathrm{Th}$ & MIS 1 & 19 & 3 & ESR, U/Th (2) & MIS 5e & $*$ & $*$ & AA (3), ESR and & MIS 7 \\
\hline & Caleta Valdez & South & 5 & 2.8 & (1 and 2) & MIS 1 & 20.5 & 1 & & MIS 5e & 32 & 1 & $\mathrm{U} / \mathrm{Th}(4,5,6)$ & MIS 7 \\
\hline \multirow[t]{5}{*}{2} & Cabo Raso & Cabo Raso & 8 & 0.5 & $*$ & MIS 1 & $\begin{array}{l}\left(\mathrm{T} 1^{\prime \prime}\right) \\
18.5\end{array}$ & 2 & * & MIS 5e & 26.5 & 2 & $*$ & MIS 7 \\
\hline & Bahia Camarones & Camarones City & 6 & 2 & $\begin{array}{l}\mathrm{C} 14, \mathrm{U} / \mathrm{Th} \\
(2 \text { and } 7)\end{array}$ & MIS 1 & 15 & 1 & ESR, U/Th (2) & MIS 5e & 24.5 & 2 & $\begin{array}{l}\text { U/Th, paleontology } \\
(4,5,6,8)\end{array}$ & MIS 7 \\
\hline & Bahia Camarones & Caleta Pedro & $*$ & $*$ & $*$ & MIS 1 & $\left(\mathrm{~T} 11^{\prime \prime}\right) 18$ & 2 & $*$ & MIS 5e & 25 & 2 & $*$ & MIS 7 \\
\hline & Bahia Bustamente & North & 11 & 2 & $*$ & MIS 1 & $*$ & $*$ & * & $*$ & 26 & 2 & ESR and U/Th, & MIS 7 \\
\hline & Bahia Bustamente & Aristizabal & 11 & 1 & $*$ & MIS 1 & 17 & 2 & $\begin{array}{l}\text { ESR and U/Th, } \\
(4,5,6)\end{array}$ & MIS 5e & 25 & 2 & $(4,5,6)$ & MIS 7 \\
\hline \multirow[t]{3}{*}{3} & San Jorge & Punta Delgada & 9.5 & 1 & $14 C(4)$ & MIS 1 & 17.5 & 1 & * & MIS 5e & 29.5 & 2 & $*$ & MIS 7 \\
\hline & Caleta Olivia & North & 11.5 & 1 & $\mathrm{U} / \mathrm{Th}$ & MIS 1 & 16.5 & 1 & ESR and U/Th, & MIS 5e & 32 & 1 & ESR and U/Th, & MIS 7 \\
\hline & Caleta Olivia & South & 8.5 & 1 & $(2,4,5,6,7)$ & MIS 1 & 17.5 & 1 & $(2,4,5,6)$ & MIS 5e & 27.5 & 5 & $(2,4,5,6)$ & MIS 7 \\
\hline \multirow[t]{4}{*}{4} & $\begin{array}{l}\text { Peninsula Deseado } \\
\text { north }\end{array}$ & Mazarredo & $\begin{array}{l}\left(\mathrm{TH}^{\prime \prime}\right) \\
10\end{array}$ & 2 & U/Th (2) & MIS 1 & 18 & 2 & $\mathrm{U} / \mathrm{Th}(2)$ & MIS 5e & $\begin{array}{l}\left(\mathrm{T} 2^{\prime \prime \prime}\right) \\
33\end{array}$ & 2 & $*$ & $\begin{array}{l}\text { MIS } \\
7 ?\end{array}$ \\
\hline & $\begin{array}{l}\text { Peninsula Deseado } \\
\text { north }\end{array}$ & Deseado & 7.5 & 1.5 & $*$ & $\begin{array}{l}\text { MIS } \\
1 ?\end{array}$ & $\left(\mathrm{~T} 11^{\prime \prime}\right) 18$ & 2 & $*$ & $\begin{array}{l}\text { MIS } \\
5 e ?\end{array}$ & 35 & 3 & $*$ & $\begin{array}{l}\text { MIS } \\
7 ?\end{array}$ \\
\hline & $\begin{array}{l}\text { Peninsula Deseado } \\
\text { south }\end{array}$ & Guanaco & $\begin{array}{l}\left(\mathrm{TH}^{\prime \prime}\right) \\
8.5\end{array}$ & 0.5 & $*$ & $\begin{array}{l}\text { MIS } \\
1 ?\end{array}$ & $\left(\mathrm{~T} 1{ }^{\prime \prime}\right) 17$ & 1 & $*$ & $\begin{array}{l}\text { MIS } \\
5 e ?\end{array}$ & 27 & 2 & $*$ & $\begin{array}{l}\text { MIS } \\
7 ?\end{array}$ \\
\hline & $\begin{array}{l}\text { Peninsula Deseado } \\
\text { south }\end{array}$ & Bahia Laura & 8.5 & 2 & $*$ & $\begin{array}{l}\text { MIS } \\
1 ?\end{array}$ & 17 & 3 & * & $\begin{array}{l}\text { MIS } \\
5 e ?\end{array}$ & 30 & 3 & $*$ & $\begin{array}{l}\text { MIS } \\
7 ?\end{array}$ \\
\hline \multirow[t]{2}{*}{5} & $\begin{array}{l}\text { San Julian and Santa } \\
\text { Cruz }\end{array}$ & San Julian & 8.5 & 1 & $\begin{array}{l}\text { ESR, U/Th } \\
(2,4,5,6)\end{array}$ & MIS 1 & 16.5 & 0.5 & $\begin{array}{l}\text { ESR, U/Th } \\
(2,4,5,6)\end{array}$ & MIS 5e & 31.5 & 3 & $\begin{array}{l}\text { ESR, U/Th } \\
(2,4,5,6)\end{array}$ & $\begin{array}{l}\text { MIS } \\
7 ?\end{array}$ \\
\hline & $\begin{array}{l}\text { San Julian and Santa } \\
\text { Cruz }\end{array}$ & Santa Cruz & 9.5 & 1 & * & $\begin{array}{l}\text { MIS } \\
1 ?\end{array}$ & $*$ & $*$ & * & * & $*$ & $*$ & * & $*$ \\
\hline 6 & Cabo Virgenes & Cabo Virgenes & 8 & 2 & $*$ & $\begin{array}{l}\text { MIS } \\
1 ?\end{array}$ & 18 & 5 & $*$ & $\begin{array}{l}\text { MIS } \\
5 e ?\end{array}$ & $*$ & $*$ & $*$ & $*$ \\
\hline \multirow[t]{3}{*}{7} & Tierra del Fuego & $\begin{array}{l}\text { Bahia San } \\
\text { Sebastian }\end{array}$ & $*$ & $*$ & $*$ & $*$ & 16 & 1 & $*$ & MIS 5e & $*$ & $*$ & $*$ & $*$ \\
\hline & & Punta Popper & $*$ & $*$ & $*$ & $*$ & 18 & 1 & $*$ & MIS 5e & $*$ & $*$ & $*$ & $*$ \\
\hline & & Isla Navarino & $*$ & $*$ & $*$ & $*$ & 10 & 1 & $*$ & MIS 5e & $*$ & $*$ & $*$ & $*$ \\
\hline
\end{tabular}

sequence has long been recognized and described (Feruglio, 1950; Rutter et al., 1989; Rostami et al., 2000; Schellmann and Radtke, 2000) (Fig. 2, Table 2). We found other evidences of coastal deformations near Puerto Piramides (Fig. 2) where we observed a sequence of two marine terraces ( $\mathrm{T} 1$ and $\mathrm{T} 2$ ). The lowest $\mathrm{T} 1$ marine terrace, which is the best preserved, has a maximum width of $60 \mathrm{~m}$ and its shoreline angle was measured at $20 \pm 5 \mathrm{~m}$ (point 1, Fig. 2). T2 is noticeable above $\mathrm{T} 1$ and its shoreline angle is present at $29 \pm 5 \mathrm{~m}$, (point 1 , Fig. 2). Given the bedrock (sandstones) and the lack of coastal sediments on the erosional morphologies, a confusion with structural surfaces is possible. T1 and T2 shoreline angles are found at altitudes very similar to the shoreline angles of T1 and T2 in Caleta Valdez and southward (as will be discussed in the later part), we propose that the observed morphologies are marine in origin.

\subsubsection{Zone 2: "Dos Bahías"}

We named this zone from the cape Dos Bahías which separates two vast embayments: Bahía Camarones to the north and Bahía Bustamante to the south (Figs. 1, 2, 3A). Both embayments extend over a $\sim 320 \mathrm{~km}$ long stretch of coast. The coastal deposits present in this area have been described extensively in the literature (Feruglio, 1950; Rutter et al., 1989; Schellmann and Radtke, 1997; Rostami et al., 2000; Schellmann and Radtke, 2000; Aguirre et al., 2005,2006; Sauer et al., 2007). We concentrated our field work in the northern and southern part of the Bahía Camarones (Cabo Raso, Camarones, Caleta Pedro) and in the southern part of Bahía Bustamante (Gravina, Aristizabal peninsulas) where paleo-shores are rocky (Table 2).

Even if this zone is abundantly described by Feruglio (1950), only a single recent article provided a brief description of it (Aguirre et al., 2006). On Cabo Raso, we observed a sequence of three marine terraces
( $\mathrm{TH}, \mathrm{T} 1$, and $\mathrm{T} 2$ ) reaching $26.5 \pm 3 \mathrm{~m}$ (Fig. 3B). The sequence is bordered to the north and south by beach ridge sequences (e.g. BR1, BR2, and Fig. 3B). On Cabo Raso, TH, T1 and T2 lack deposits and overlook a rocky coast characterized by abrasion platform. TH is found continuously over more than $10 \mathrm{~km}$. We measured its shoreline angle altitude in the bay, north of Cabo Raso, at $9.5 \pm 0.5 \mathrm{~m}$ (point 1, Fig. 3B) and on the Cabo Raso itself at $8 \pm 0.5 \mathrm{~m}$ (point 2, Fig. 3B). The difference in altitude comes from the deposits (i.e. storm deposits) found in the bay and a lack of coastal deposits on the paleo-shore platform. T1, wider than $\mathrm{TH}$, extends all over the cape along a 7-km long stretch of coast. On Cabo Raso, the T1 marine terrace is compound; it includes 2 "second-order" terraces, characterized by their shoreline angles ( $1^{\prime}$ at $14.5 \pm 2 \mathrm{~m}$ and $\mathrm{T} 1$ at $18.5 \pm 2 \mathrm{~m}$ ). T1 corresponds to the 15-20 m terrace described by Feruglio (1950) on Cabo Raso. T1 and TH are overlooked by T2, over at least $7 \mathrm{~km}$ (Fig. 3B). The T2 shoreline angle was measured at an altitude of $26.5 \pm$ $3 \mathrm{~m}$, which may correspond to the internal beach ridge described by Feruglio (1950) in Caleta Raso (the bay south of Cape Raso) where he found Chione antiqua and Mactra Isabelleana. The connection of the marine terrace to the beach ridge sequence is located at the transition between the cape and the northern bay, but observation of this transition is difficult because of paleolagoon and pond deposits (mapped on Fig. 3B) also described by Feruglio (1950). The latter found higher terraces at $44 \mathrm{~m}$ and $76 \mathrm{~m}$ which may correspond to the uppermost inferred shoreline angle mapped on Fig. 3A.

\subsubsection{Zone 3: Golfo San Jorge}

Golfo San Jorge is $240 \mathrm{~km}$ in extent and passes landward over $150 \mathrm{~km}$ (Fig. 4). Darwin provided a section of the step-formed plains of this zone and identified 7 levels reaching an elevation of $365 \mathrm{~m}$. The 


\begin{tabular}{|c|c|c|c|c|c|c|c|c|c|c|c|c|c|c|c|c|c|}
\hline \multicolumn{4}{|l|}{ T3 } & \multicolumn{4}{|l|}{$\mathrm{T} 4$} & \multicolumn{2}{|l|}{ T5 } & \multicolumn{2}{|l|}{ T6 } & \multicolumn{2}{|l|}{$\mathrm{T} 7$} & \multicolumn{2}{|l|}{$\mathrm{T} 8$} & \multicolumn{2}{|l|}{ T9 } \\
\hline E & MoE & Dating & CS & $\mathrm{E}$ & MoE & Dating & CS & $\mathrm{E}$ & MoE & $\mathrm{E}$ & $\mathrm{MoE}$ & $\mathrm{E}$ & MoE & $\mathrm{E}$ & MoE & $\mathrm{E}$ & $\mathrm{MoE}$ \\
\hline * & $*$ & & $*$ & $*$ & $*$ & $*$ & * & $*$ & * & $*$ & * & $*$ & * & * & $*$ & $*$ & $*$ \\
\hline * & $*$ & ESR and U/Th $(4,5,6)$ & MIS 9 & 44 & 3 & * & MIS $11 ?$ & $*$ & * & * & $*$ & * & * & * & * & $*$ & * \\
\hline 35.5 & 1.1 & & MIS 7 or $9 ?$ & $*$ & $*$ & * & $*$ & $*$ & $*$ & * & * & $*$ & * & $*$ & $*$ & $*$ & $*$ \\
\hline$*$ & $*$ & $*$ & $*$ & $*$ & $*$ & * & $*$ & * & * & * & $*$ & * & * & $*$ & * & $*$ & $*$ \\
\hline 41.5 & 1.5 & ESR and $\mathrm{U} / \mathrm{Th},(4,5,6)$ & MIS 9 & * & $*$ & $*$ & * & * & * & * & * & * & * & * & $*$ & $*$ & * \\
\hline * & $*$ & $*$ & $*$ & $*$ & $*$ & $*$ & * & $*$ & * & $*$ & $*$ & $*$ & * & * & * & * & $*$ \\
\hline 41 & 3 & $*$ & $*$ & $*$ & $*$ & $*$ & * & * & * & * & $*$ & $*$ & * & $*$ & * & * & $*$ \\
\hline 46 & 3 & * & $*$ & (T4?) 83 & 10 & $*$ & * & * & * & * & * & * & * & * & $*$ & $*$ & $*$ \\
\hline * & * & * & * & * & $*$ & * & * & * & $*$ & $*$ & * & $*$ & * & * & $*$ & * & * \\
\hline * & * & * & $*$ & * & $*$ & * & * & * & * & $*$ & * & $*$ & * & $*$ & $*$ & * & * \\
\hline 46 & 5 & $*$ & MIS 9 & $*$ & $*$ & * & $*$ & $*$ & * & $*$ & $*$ & $*$ & * & $*$ & * & $*$ & $*$ \\
\hline 44 & 2 & $*$ & $*$ & 62 & 5 & $*$ & * & $*$ & * & $*$ & $*$ & $*$ & $*$ & $*$ & $*$ & $*$ & $*$ \\
\hline 46 & 5 & $*$ & $*$ & 56 & 5 & $*$ & * & 73 & 5 & 86 & 5 & 105 & 5 & 129 & 5 & 142 & 10 \\
\hline 49 & 5 & $*$ & $*$ & 76 & 4 & $*$ & * & $*$ & $*$ & $*$ & $*$ & $*$ & * & * & $*$ & $*$ & $*$ \\
\hline$*$ & * & * & * & * & $*$ & * & * & * & * & * & * & * & * & * & $*$ & * & $*$ \\
\hline 50 & 5 & $*$ & $*$ & 81 & 10 & * & * & * & * & $*$ & * & $*$ & * & * & $*$ & * & $*$ \\
\hline$*$ & * & * & * & $*$ & $*$ & * & * & * & * & $*$ & $*$ & * & $*$ & $*$ & * & $*$ & * \\
\hline * & * & $*$ & * & * & * & * & * & $*$ & * & * & * & * & * & * & * & * & * \\
\hline$*$ & * & * & $*$ & * & * & * & * & * & * & $*$ & * & $*$ & * & * & * & * & * \\
\hline * & * & * & $*$ & * & * & * & * & * & * & * & * & * & * & $*$ & * & * & * \\
\hline * & * & * & $*$ & $*$ & * & * & * & * & $*$ & $*$ & $*$ & * & * & * & $*$ & * & * \\
\hline
\end{tabular}

three major levels lie at $\sim 176 \mathrm{~m}$ (in Rada Tilly), $\sim 100 \mathrm{~m}$, and $\sim 76 \mathrm{~m}$. This zone has been also extensively studied by Feruglio (1950), Aguirre (2003), Schellmann and Radtke (1997, 2000), and Rostami et al. (2000). In this zone, we concentrated our field work in Punta Delgada, (near the former factory of Sindicato Dodero, Fig. 5A) and in the vicinity of Caleta Olivia (Fig. 5B).

Punta Delgada lies approximatively $25 \mathrm{~km}$ south of Comodoro Rivadavia (Fig. 4) near the former village of Sindicato Dodero. In this zone, we observed a coastal sequence including beach ridges and marine terraces ( $\mathrm{TH}, \mathrm{T} 1$ and $\mathrm{T} 2$ ). $\mathrm{TH}$ is represented by a beach ridge sequence which extends over a $3 \mathrm{~km}$ long coastal stretch and has a maximum width of $2.8 \mathrm{~km}$ (Holocene, Schellmann and Radtke, 2003). We measured its shoreline angle at $9.5 \pm 1 \mathrm{~m}$ (point 1, Fig. 5A), which corresponds to the measurements of Feruglio (1950) and Schellmann and Radtke (2003). We found two terraces (T1 and T2) overlooking the Holocene terrace. T1 shoreline angle is orientated W-E and the terrace is quite reduced in width (i.e. less than $50 \mathrm{~m}$ ). T1 shoreline angle was measured at an altitude of $17.5 \pm 1 \mathrm{~m}$ on the southern flank of Punta Delgada. We suggest a possible cannibalization by the late Middle Holocene littoral terrace. The highest terrace of the area, T2, is present on the summit of Punta Delgada.; its shoreline angle was measured at $29.5 \pm 2 \mathrm{~m}$ (Fig. $5 \mathrm{~A}$ ). On the surface of T2 we observed broken shells of Fisurella sp., Protothaca sp., and Mytilus sp. in a sandy matrix. T2 has a maximum width of $300 \mathrm{~m}$. To the west, it seems that there is another level of terrace overlooking T2 (altitude of $\sim 40 \mathrm{~m}$ ) but we observed gravels and boulders that may belong to continental deposits (i.e. Rodados Patagonicos) and no evident break in slope corresponding to a shoreline angle is observed in the landscape. T2 is also present at an altitude of $29 \pm 2 \mathrm{~m} 2 \mathrm{~km}$ north of Punta Delgada, overlooking Asina beach and easily noticeable in the landscape.
South of Caleta Olivia (75 km south of Comodoro Rivadavia), we identified three marine terraces (Figs. 4, 5B). Because of the substratum, they are not well marked in the area which may explain that no map has been previously proposed yet. A striking characteristic of the area is that the paleoshores do not conform to the modern one. With the exception of the Holocene paleoshoreline, they present an arched repartition defining paleo-embayments. We show evidence for three of these paleo-embayments but there are probably more. The three paleo-embayments are about $3 \mathrm{~km}$ long and extend $\sim 1.5 \mathrm{~km}$ inland. Four shoreline angles reach a maximal elevation of $46 \pm 5 \mathrm{~m}$. As observed in the landscape, there are higher marine terraces but because these features are heavily eroded, we did not find any break in slope (i.e. shoreline angle) preserved sufficiently to be measured. TH is nearly continuous from Bahía Solano to Bahía Langara (see Fig. 4) at $7.5 \pm 1 \mathrm{~m}$, north of Caleta Olivia(point 9, Fig. 5B)and at $11.5 \pm 1 \mathrm{~m}$ (point 6 , Fig. $5 \mathrm{~B}$ ) and $8.5 \pm 1 \mathrm{~m}$ (point 1 , Fig. $5 \mathrm{~B}$ ) south of Caleta Olivia. This discrepancy is related to the nature of the break in slope interpreted as the shoreline angle. Point 6 probably corresponds to a junction between "normal" shore sediments and storm debris whereas points 1 and 9 are junctions between "normal" deposits and a steep sea cliff. Samples from TH (taken north and south of Caleta Olivia) were U/Th dated (Schellmann and Radtke, 1997; Rostami et al., 2000) and TH was consequently correlated by these authors to the maximum Holocene transgression. We measured the T1 shoreline angle altitude in the northern and southernmost embayments at altitudes of $16.5 \pm 1 \mathrm{~m}$ (point 7, Fig. 5B) and $17.5 \pm 3 \mathrm{~m}$ (point 2, Fig. 5B), respectively. Samples from T1 (taken south of Caleta Olivia) were U/Th and ESR dated and correlated to MIS 5e (Rostami et al., 2000). In all three embayments, T1 is overlooked by T2, which we found from north to south raised at $29.5 \pm 1.5 \mathrm{~m}$ (point 8 , Fig. $5 \mathrm{~B}$ ), $32 \pm 1 \mathrm{~m}$ (point 5 , Fig. $5 \mathrm{~B}$ ) 


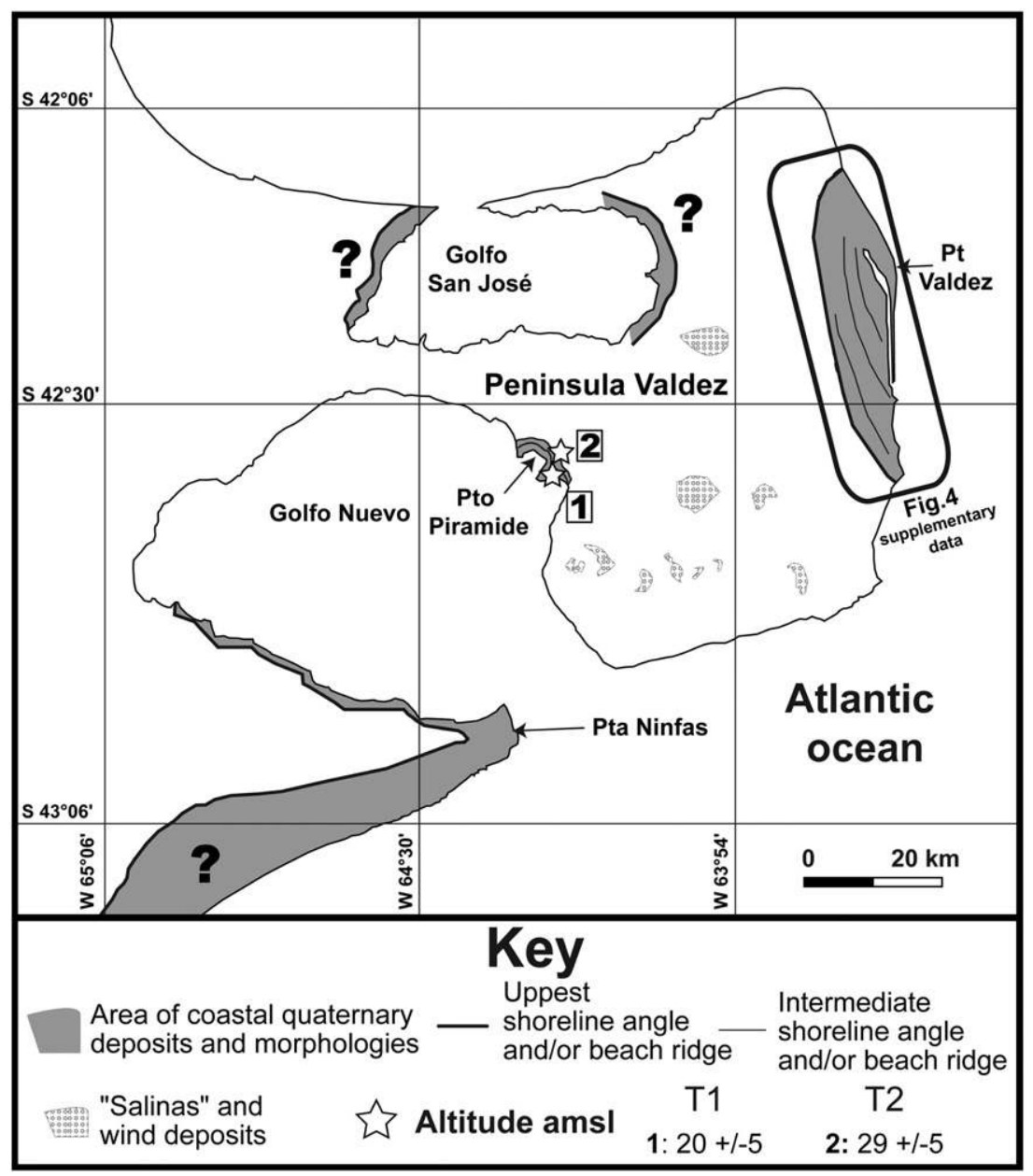

Fig. 2. Quaternary coastal sequences on Peninsula Valdez (Zone 1).

and $27.5 \pm 5 \mathrm{~m}$ (point 3, Fig. 5B). The altitude of the shoreline angle of the highest preserved marine terrace, T3, was measured at $46 \pm 5 \mathrm{~m}$ (point 4, Fig. 5B) in the southernmost paleo-embayment. In this area deposits sampled at 10,17, $20 \mathrm{~m}$ and $25 \mathrm{~m}$ were ESR and/or U/Th dated and related to MIS 5, 7, 9 and 11 but with no explicit reference to the altitude of past shorelines (Schellmann, 1998; Schellmann and Radtke, 2000, 2003).

\subsubsection{Zone 4: Peninsula Deseado}

We call Peninsula Deseado the whole macro-peninsula extending from Puerto Mazarredo in the north to a point located $30 \mathrm{~km}$ south of Punta Campana in the south (Fig. 6A). The macro-peninsula is about $175-\mathrm{km}$ long and $75-\mathrm{km}$ large. Its coastal fringe is covered by littoral Quaternary morphologies and deposits (Fig. 6A). In this area the best studied sites are Mazarredo (Table 2) and the vicinity of Puerto Deseado. Note that for the latter, no map was provided in previous studies. Even less attention has been paid to the southern part of the peninsula, south of the Deseado river.

Puerto Deseado lies on the northern bank of the Río Deseado, about $250 \mathrm{~km}$ southeast of Comodoro Rivadavia (Fig. 1, 6B). Darwin (1842) identified four levels of marine terraces, and measured the three lowest with a barometer, at about $30,74-77$ and $100 \mathrm{~m}$. On the 74 and $100 \mathrm{~m}$ levels he identified shells of Mytilus, Magellanicus, M. edulis, and Patella deaurita and made the observation that these species were the commonest living on the coast at the moment of his visit. Later workers (Feruglio, 1950; Rutter et al., 1989) described a sequence including five marine terraces and/or beach ridges reaching a maximum elevation of $186 \mathrm{~m}$. In this area, we found a sequence of 10 marine terraces reaching $142 \pm 10 \mathrm{~m}$ in elevation. The terrace distribution conform to the modern shoreline direction, shifting from $\mathrm{N}-\mathrm{S}$ direction (open ocean side) to $\mathrm{E}-\mathrm{W}$ (northern bank of the Río Deseado) (Fig. 6B).

On the $\mathrm{N}-\mathrm{S}$ shore, $\mathrm{TH}$ consists of a gravel beach ridge sequence which sharply ends to the south on a small tombolo (Fig. 6B). At the outlet of the Río Deseado, TH consists in a paleo-abrasion platform with scarce sediments reaching a maximum width of $110 \mathrm{~m}$, at an elevation of $7.5 \pm 1.5$ (Point 10, Fig. 6B) and $9.5 \pm 1.5$ (Point 10', Fig. 6B). Point 10 corresponds to a measurement made by distance meter on an islet of the Río Deseado whereas Point $10^{\prime}$ corresponds to a measurement on the eastern entrance of the city. We do rely more on the measurements made with altimeters rather than the estimation made with distance meter. The first marine terrace (T1) overlooking TH is present along the open-ocean shore and the Río Deseado shore. East of Puerto Deseado, T1 is the first terrace overlooking the modern abrasion platform. As for $\mathrm{TH}$, we took measurements with altimeters (points 1 and $11^{\prime}$, Fig. 6B) on land but also with distance meter on the islet present in the Río Deseado outlet. The same discrepancy appears between the measurements. We consider that the shoreline angle of $\mathrm{T} 1$ is present at a maximum elevation of $18 \pm 2 \mathrm{~m}$ (points 1 and $11^{\prime}$ ) when it was measured at $13 \pm 3 \mathrm{~m}$ on the islet. The second Pleistocene terrace (T2) is found continuously in the zone and the elevation of its shoreline was measured to the east and to the west of Puerto Deseado at $35 \pm 5 \mathrm{~m}$ to the east (point 2, Fig. 6B) and at $35 \pm 3 \mathrm{~m}$ to the west (point 12, Fig. 6B). The third Pleistocene terrace (T3) is overlooking T2, T1 and TH and its shoreline was measured at $46 \pm 5 \mathrm{~m}$ (point 3, Fig. 6B) to the east of Puerto Deseado and at $52 \pm$ $15 \mathrm{~m}$ to the west of the city (point 13, Fig. 6B). Given the error range of the measurement at point 13 , we do not consider that there is a 

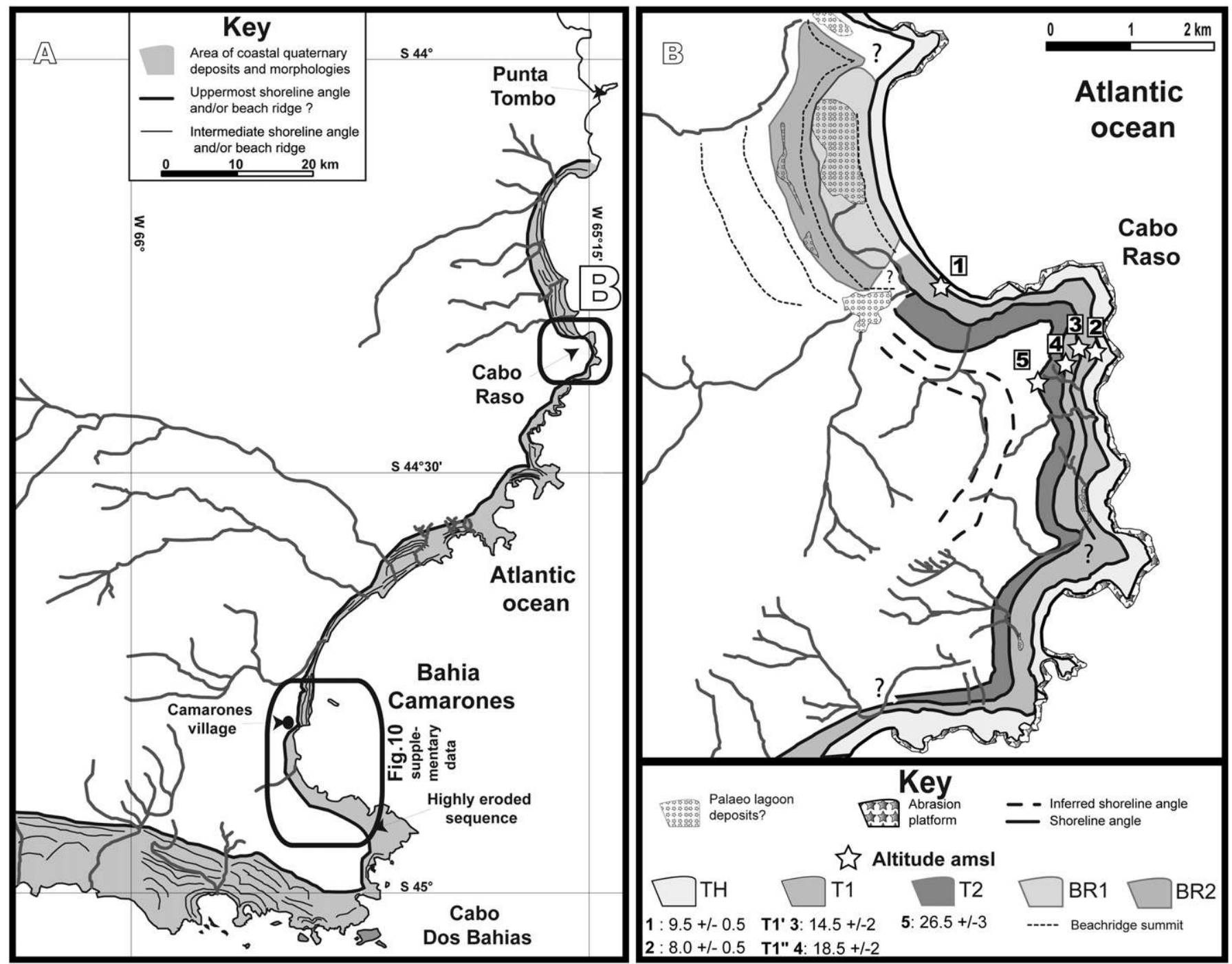

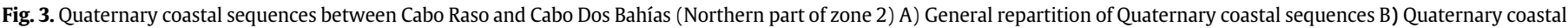
sequences on Cabo Raso.

significant difference in altitude between point 3 and point 13 (Fig. 6B). Immediately west of Puerto Deseado, the shoreline of T3 is not easily noticeable in the landscape, probably because of anthropic reworking (see question mark, Fig. 6B). T4 is easily recognizable to the northeast of Puerto Deseado where it extends over $4 \mathrm{~km}$. It is much more eroded west of the city (see inferred shoreline, Fig. 6B). Its shoreline angle lies at $56 \pm 5 \mathrm{~m}$ (point 4 , Fig. $6 \mathrm{~B}$ ). T5 is observable to the northeast of Puerto Deseado where it extends over $2 \mathrm{~km}$, as T4 but, it is much more eroded to the west of the city. We measured its shoreline angle elevation at $73 \pm 5 \mathrm{~m}$ (point 5 , Fig. 6B). This marine terrace corresponds to the terrace of the Cerro Alonso described by Feruglio (1950).

The whole inland extent of marine terraces TH, T1, T2, T3, T4 and T5 reaches a width of $3.5 \mathrm{~km}$. At about $10 \mathrm{~km}$ from the coast, $8 \mathrm{~km}$ east of Tellier village, we found other evidences of paleoshorelines. We named the four upper marine terraces T6, T7, T8 and T9 (Fig. 6B) but intermediate shoreline angles are probably present between $\mathrm{T} 5$ and T6 (see inferred shoreline angle, Fig. 6B). T6 is about $4 \mathrm{~km}$-wide and probably constitutes a polygenic terrace for which the intermediate shorelines angles are not observable on field (i.e. rasa sensu Guilcher, 1974). The shoreline angles of T6, T7, and T8 were measured at $86 \pm$ $5 \mathrm{~m}$ (point 6), $105 \pm 5 \mathrm{~m}$ (point 7), and $129 \pm 5 \mathrm{~m}$ (point 8) respectively. In this area, we found a paleo-abrasion platform (T9) overlooking T6, T7, and T8 with no associated shoreline angle at an altitude of $142 \pm 10 \mathrm{~m}$. Parts of this terrace (T8 and T9) probably correspond to the terrace of the Cabo Tres Puntas (see Fig. 6A for location) described by Feruglio (1950). The marine origin of these terraces is demonstrated by fossiliferous deposits that Feruglio (1950) described. An upper marine terrace level must be present, as Feruglio (1950) described high mesetas (Terraza del Cerro Laciar) up to 170 to $186 \mathrm{~m}$ in elevation. He found a fossiliferous site and analyzed the fauna: he correlated this level to the Pliocene because $47 \%$ of the mollusks he described were extinct.

The coastal fringe of the southern part of the Deseado peninsula is totally covered by Quaternary deposits and morphologies (Fig. 6A). In this area we focused our attention in two zones: Punta Guanaco and Bahía Laura, at a distance of $95 \mathrm{~km}$.

Punta Guanaco is a small cape $20 \mathrm{~km}$ south of Puerto Deseado (Fig. 6A). Feruglio (1950) described two marine terraces reaching a maximal altitude of $61.5 \pm 1.5 \mathrm{~m}(60-63 \mathrm{~m})$. The lower one is 500 to $1000 \mathrm{~m}$ wide with a shoreline angle raised at $19 \pm 1 \mathrm{~m}$. On the northern part of Punta Guanaco, we observed a complete sequence of five marine terraces and notches reaching a maximal elevation of $76 \pm 4 \mathrm{~m}$ (Fig. 7A). The point is totally covered by a complex marine terrace sequence which extends northwards and southwards. Northwards, the sequence ends up on the southern bank of Río Deseado. Southwards, it continues 


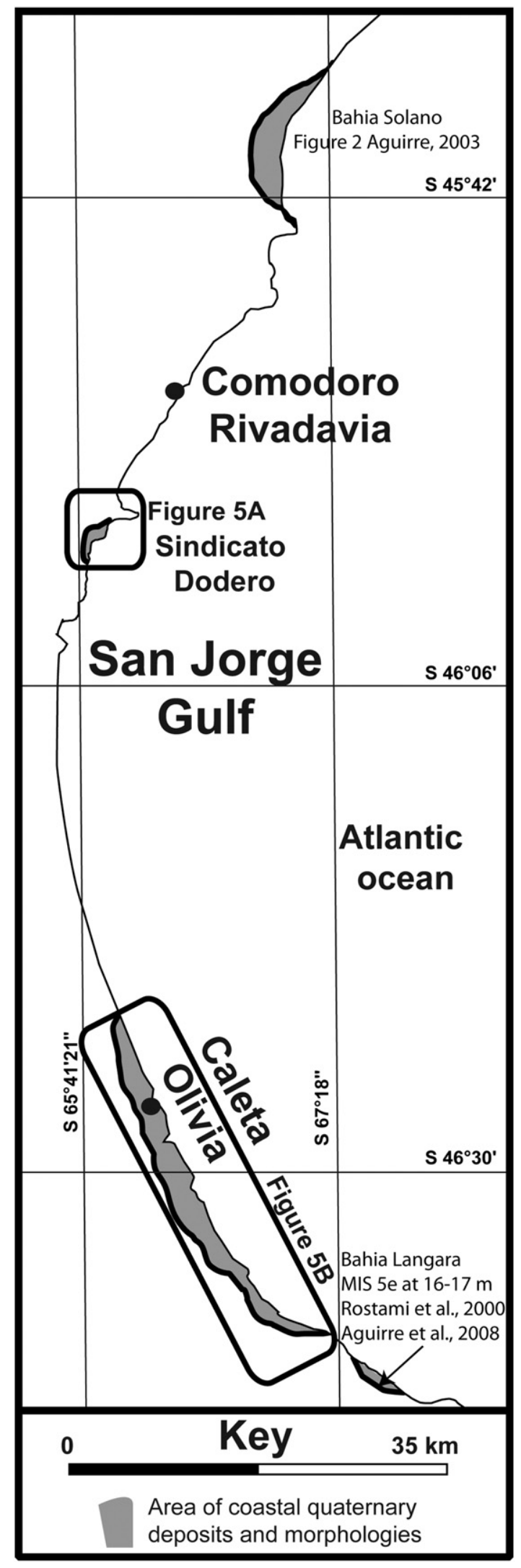

Fig. 4. Quaternary coastal sequences in San Jorge Gulf (Zone 3).

to Bahía Laura and Punta Campana (as will be discussed in the later part). In Punta Guanaco the modern shoreline is rugged and heavily circumvallated. The marine terraces in the zone are abrasion platforms or notches without any marine deposit. The marine origin of theses morphologies is emphasized by the observation of lateral continuity with beach ridges sequences. We measured two altitude transects: $\mathrm{W}$ and $\mathrm{E}$ (points $1-5$ and $6-10$, respectively, Fig. $7 \mathrm{~A}$ ). $\mathrm{TH}$ is found as a sequence of two notches (point 1 and 2, Fig. 7A) to the west but also as a single marine terrace to the east. The two notches are present in a small embayment and are distant by about $30 \mathrm{~m}$. They lie respectively at $5 \pm 1$ and $8.5 \pm 0.5 \mathrm{~m}$. They are 1.2 and $1.5 \mathrm{~m}$ high and have retreat points 0.7 and $2 \mathrm{~m}$ deep, respectively. Three $\mathrm{km}$ eastwards, the TH shoreline angle is at the same altitude of $8.5 \pm 0.5 \mathrm{~m}$ (point 6, Fig. 7A). TH is also present to the east of Punta Guanaco, all around Bahía Oso Marino and to the south of Punta Guanaco, but it is there very rugged, precluding any measurement. As in Cabo Raso, T1 is a compound terrace. In fact, two paleo-abrasion platforms ( $\mathrm{T}^{\prime}$ and $\left.\mathrm{T} 1^{\prime \prime}\right)$ are separated by a small scarp (i.e. less than $2 \mathrm{~m}$ ). We measured the shoreline angle of $\mathrm{T}^{\prime}{ }^{\prime}$ to the northwest of the Punta Guanaco (point 3, Fig. 7A) at an elevation of $14 \pm$ $2 \mathrm{~m}$. There the paleo-abrasion platform is reduced $(<5 \mathrm{~m})$, extends along $20 \mathrm{~m}$ and is backed by a notch $2 \mathrm{~m}$ high and $3 \mathrm{~m}$ deep. At Punta Norte (east of Punta Guanaco), T1' is a paleo-abrasion platform with no deposit and whose shoreline angle lies at $12 \pm 3 \mathrm{~m}$ (point 11, Fig. 7A). Immediately above $\mathrm{T} 1{ }^{\prime}$ we observed $\mathrm{T} 1$ which is more developed and with a shoreline angle at $17 \pm 1 \mathrm{~m}$ to the north of Punta Norte (point 7 , Fig. 7A). T2 overlooks T1 and is very well preserved to the north of Guanaco point where its shoreline angle was measured at $25 \pm 2 \mathrm{~m}$ (point 4, Fig. 7A) to the west and $27 \pm 2 \mathrm{~m}$ (point 8, Fig. 7A) to the east. T3 is also well preserved with a shoreline angle at $40 \pm 10 \mathrm{~m}$ (point 5 , Fig. 7A) to the west and $49 \pm 5 \mathrm{~m}$ (point 9, Fig. 7A) to the east. These measurements could be considered as similar, given their relative errors. The upper marine terrace we recognized in the area is T4 whose shoreline angle has been measured at $76 \pm 4 \mathrm{~m}$ to the NE of Punta Guanaco (point 10, Fig. 7A). We suggest that this upper level is the same as the upper marine terrace described by Feruglio (1950).

Between Punta Guanaco and Cabo Guardian, coastal morphologies and deposits are present along $90 \mathrm{~km}$ (Fig. 6A). They are particularly well developed in Punta Mendanosa but there the coast and the paleo-coasts are extremely rugged and heavily circumvallated, precluding precise observation. In Bahía Laura, Feruglio (1950) described a $5 \mathrm{~km}$-wide sequence of beach ridges reaching an altitude of 8-10 m. We concentrated our investigation on Cabo Guardian and on Punta Campana, respectively north and south of Bahía Laura, and we describe a sequence of at least five marine terraces, the shoreline angle of the three lowest (TH, T1, and T2) being measured (Fig. 7B). Holocene deposits and morphologies are represented here by 1) a sequence of beach ridges along Bahía Laura, 2) a notch on the Punta Mercedes (Fig. 7B), and 3) a marine terrace on the southern part of Punta Campana (Fig. 7B). The horizontal correlation between the notch and the beach ridge sequence was observed at the southern end of Bahía Laura. No direct horizontal correlation was observed between the notch and the abrasion platform. The notch is very regular in the landscape (see supplementary data Fig. 25A) and is $\sim 2 \mathrm{~m}$ high, $\sim 4 \mathrm{~m}$ deep (see supplementary data Fig. 25).and $8.5 \pm 2 \mathrm{~m}$ in elevation (point 1, Fig. 7B). The marine terrace on the southern flank of Punta Campana is $\sim 70 \mathrm{~m}$ in extent and does not possess any sedimentary cover. It is backed by a $\sim 20 \mathrm{~m}$ high cliff whose shoreline angle is at $8.5 \pm 1 \mathrm{~m}$. The TH marine terrace is also present around Cabo Guardian and on the islet fronting it but in this area the shoreline angle is not clear enough in the landscape to be measured. We observed T1 only on the northeastern part of the studied zone. T1 is well developed northwest of Cabo Guardian (see Fig. 7B). On the southeastern part of Bahía Laura and on Punta Campana, it has probably been cannibalized by $\mathrm{TH}$. T1 is built by a sequence of gravelly beach ridges. North of Cabo Guardian, we measured the shoreline angle of $\mathrm{T} 1$ at an altitude of $17 \pm 3 \mathrm{~m}$. T2 is present all over the zone and consists of a sequence of gravelly beach ridges in the paleo-embayment, whereas it is represented by a $300 \mathrm{~m}$-wide paleoabrasion platform without marine sediments at Punta Campana where its shoreline angle was measured at $30 \pm 3 \mathrm{~m}$ (point 4, Fig. 7B). 

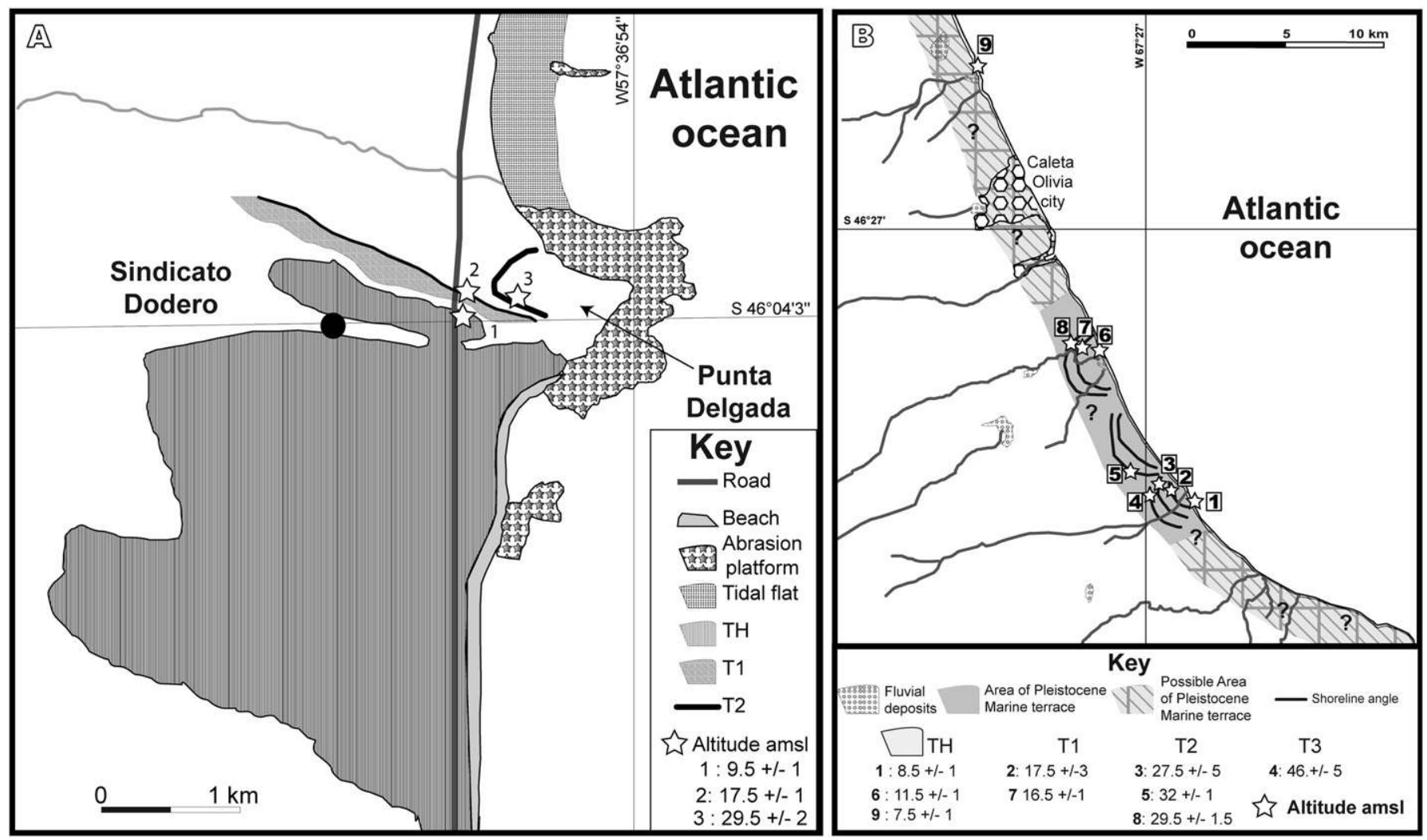

Fig. 5. A) Quaternary coastal sequence in Punta Delgada B) Quaternary coastal sequences around Caleta Olivia.
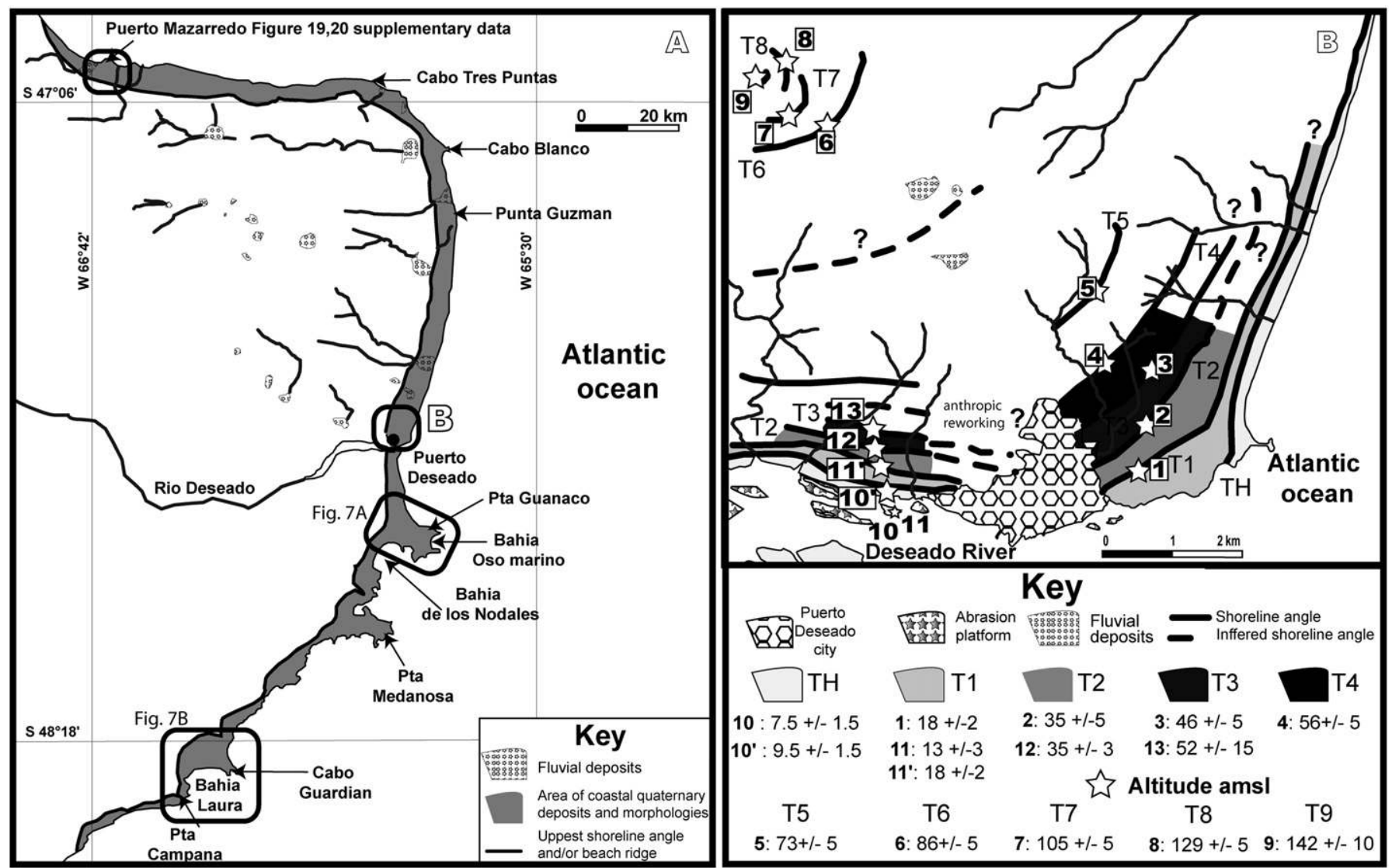

Fig. 6. A) Quaternary coastal sequences in Peninsula Deseado (Zone 4), B) Quaternary coastal sequence on the northern bank of the Río Deseado. 


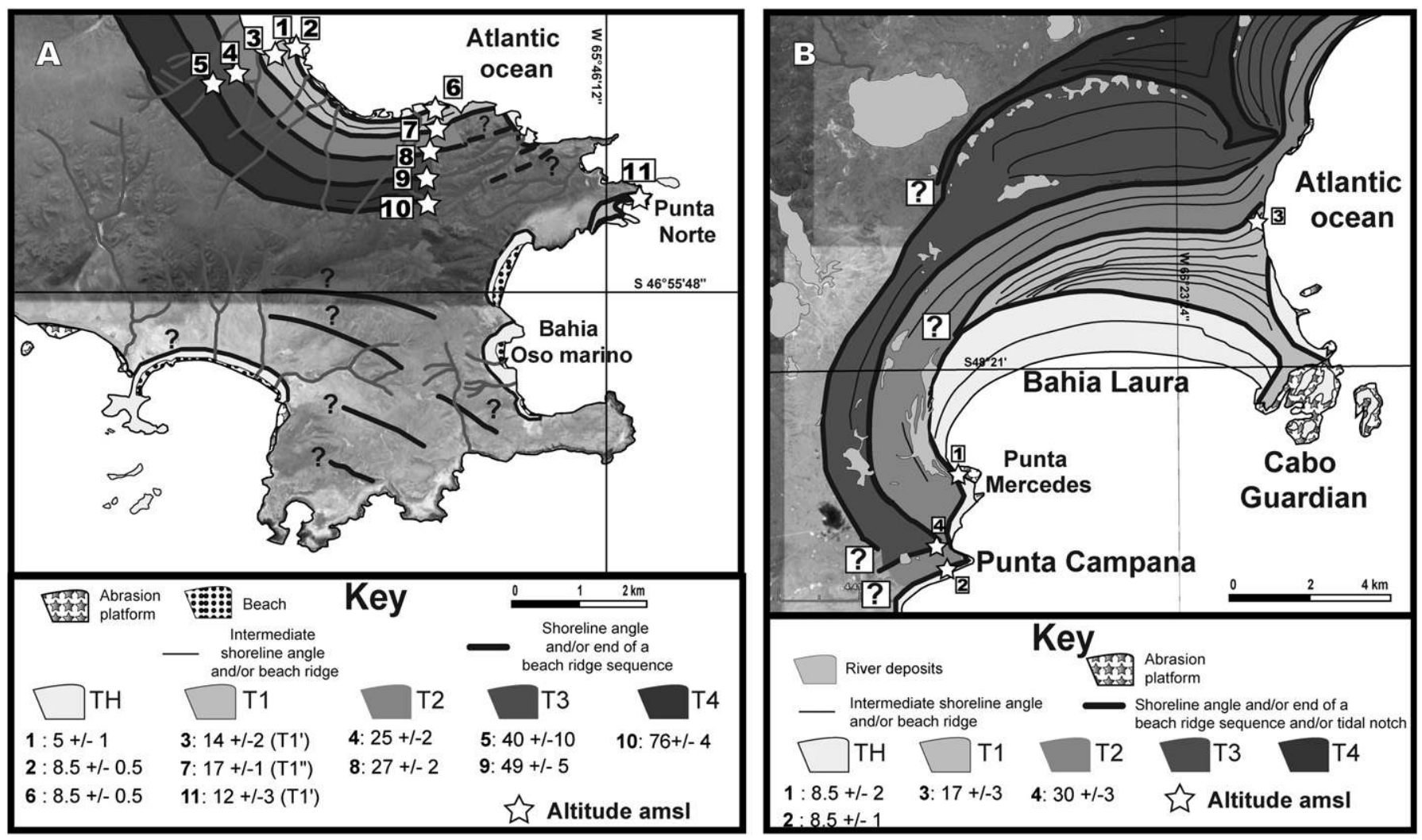

Fig. 7. A) Quaternary coastal sequence in Punta Guanaco B) Quaternary coastal sequence in Bahía Laura.

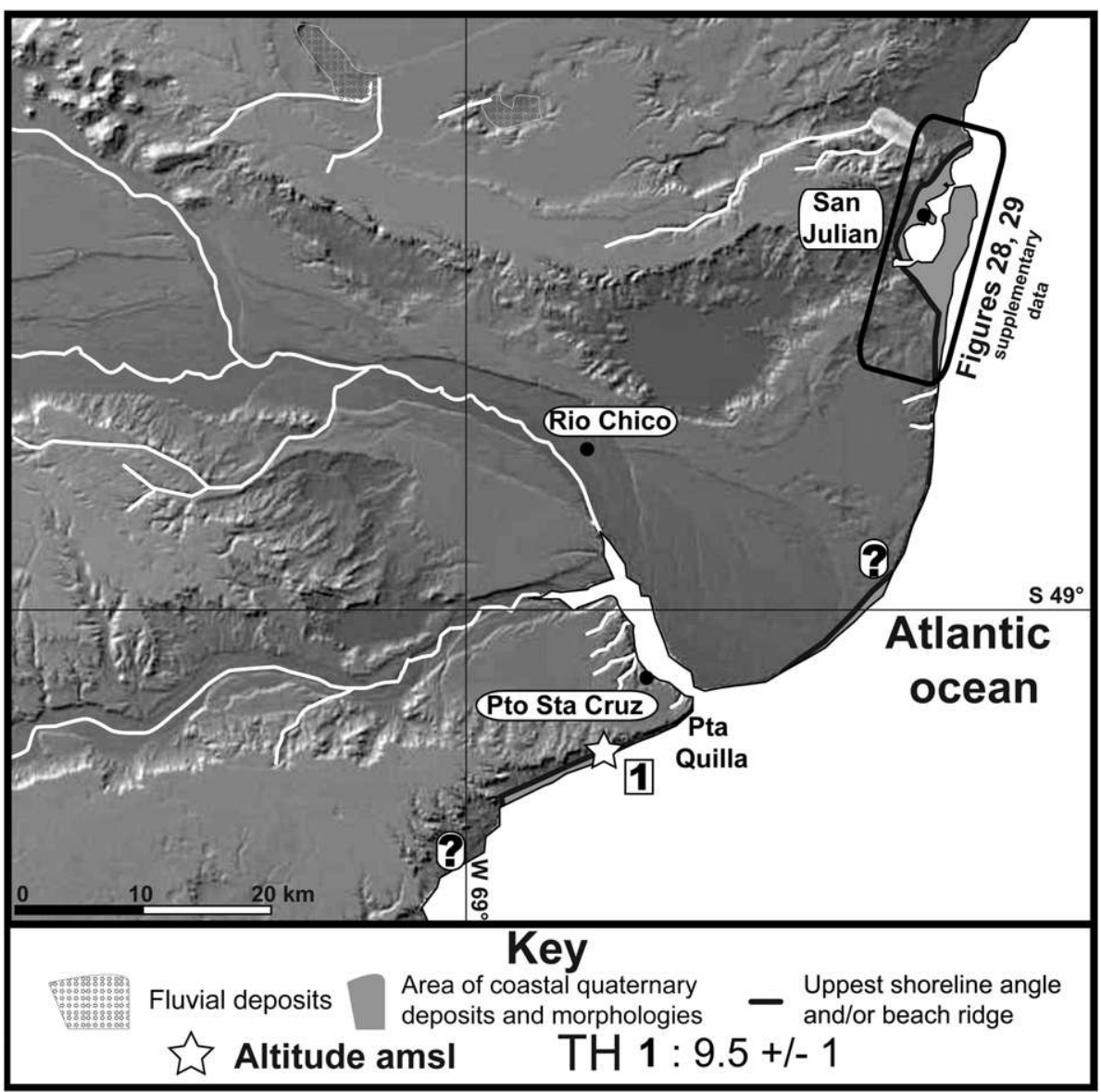

Fig. 8. Quaternary coastal sequences between San Julian and Puerto Santa Cruz (Zone 5). 


\subsubsection{Zone 5: San Julian and south of Puerto Santa Cruz}

This area encompasses San Julian (see supplementary data) and Puerto Santa Cruz (Fig. 8). In the area south of Puerto Santa Cruz the morphology consists of a pure abrasion platform extending for $300 \mathrm{~m}$ along the coast. The terrace is only $5 \mathrm{~m}$-wide, and on top of it we observed patches of unconsolidated deposits of boulders and gravel taken in a sandy matrix at $9.5 \pm 1 \mathrm{~m}$. Discussion arises about the possible occurrence of storm deposits at such an altitude. As a preliminary result we suggest that a low-standing marine terrace, probably of Holocene age, is present in the area but this hypothesis should be confirmed by further observations.

\subsubsection{Zone 6: Cabo Virgenes}

This area lies on the northern bank of the Strait of Magellan. Cabo Virgenes is the northern cape of a triangular, cuspate foreland that projects $7 \mathrm{~km}$ into the strait (Punta Dungeness on Fig. 9) and measures $8 \mathrm{~km}$ at its base. It is made up of Holocene coastal deposits (González Bonorino et al., 1999) that, following our standard practice we named it $\mathrm{TH}$. Its highest shoreline angle lies at $8 \pm 2 \mathrm{~m}$ (point 1 Fig. 9). It was described as backed to a $50 \mathrm{~m}$ high marine paleocliff with a terrace associated to a well marked break in slope at $18 \pm 5 \mathrm{~m}$ (point 2 Fig. 9). The terrace (T1) is covered by $1 \mathrm{~m}$ of sand overlain by soil and aeolian deposits, without marine fossils. It is located close to a stream erosion zone (see "unnamed" stream in Fig. 9). We cannot totally discard the interpretation that this terrace is fluvial in origin. If $\mathrm{T} 1$ is of marine origin, it should be related to the Last Interglacial
Maximum (MIS 5e) by correlation with what has been found elsewhere. Further investigation and dating in this area are necessary to 1 ) determine whether this terrace is marine or alluvial, and 2) sample some deposits and/or fauna in order to get absolute ages.

\subsubsection{Zone 7: Tierra del Fuego}

In Tierra del Fuego, Holocene and Late Pleistocene (MIS 5e) shorelines are found in two zones: (1) Bahía San Sebastian and (2) Río Grande and Isla Navarino (see supplementary data Fig. 31).

San Sebastian bay is a large semi-circular coastal embayment partially enclosed by a southward elongated gravel spit. Its size is approximately $40 \mathrm{~km}$ from north to south and $25 \mathrm{~km}$ from east to west. In this area overlooking a Holocene beach ridge and chenier sequence, the MIS 5e marine terrace stands at $16 \pm 1 \mathrm{~m}$ (Fig. 30B) (Rutter et al., 1989; González Bonorino et al., 1999; Vilas et al., 1999). To the south of the bay, it is present at $18 \pm 1 \mathrm{~m}$ (Bujalesky, 1999; Bujalesky and Isla, 2006; Bujalesky, 2007) whereas it was described at $10 \pm 1 \mathrm{~m}$ on the northern coast of Isla Navarino (Ortiz-Troncoso, 1979; Bujalesky, 2007; Rabassa et al., 2008). Around San Sebastian, Middle Pleistocene coastal deposits are described up to $29 \mathrm{~m}$ (Bujalesky, 1999).

\subsection{Tentative chrono-stratigraphic interpretation and uplift rates}

All over Eastern Patagonia, the best dated marine terraces correspond to the Holocene and the Last Interglacial Maximum (MIS

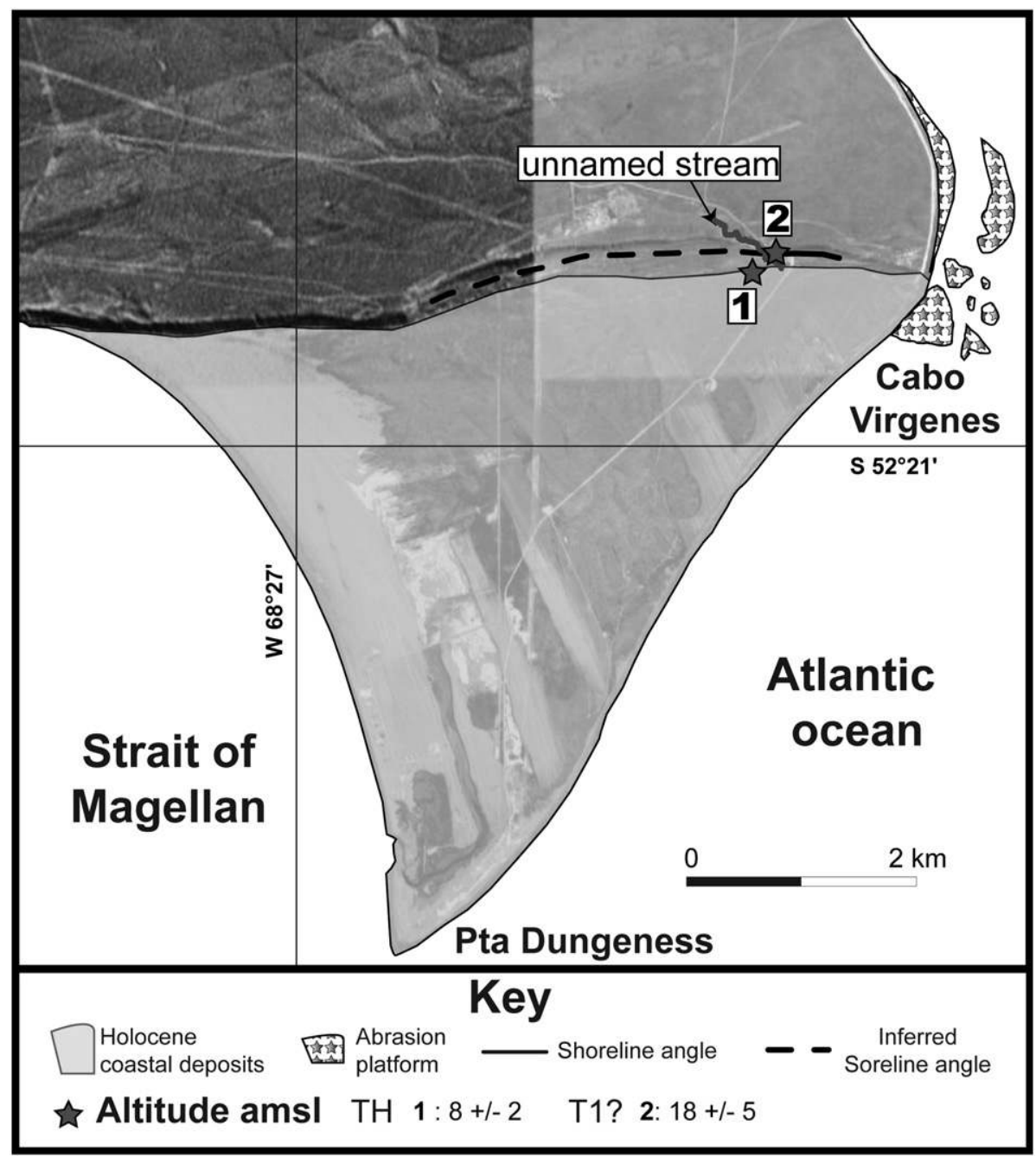

Fig. 9. Quaternary coastal sequences in Cabo Virgenes. 


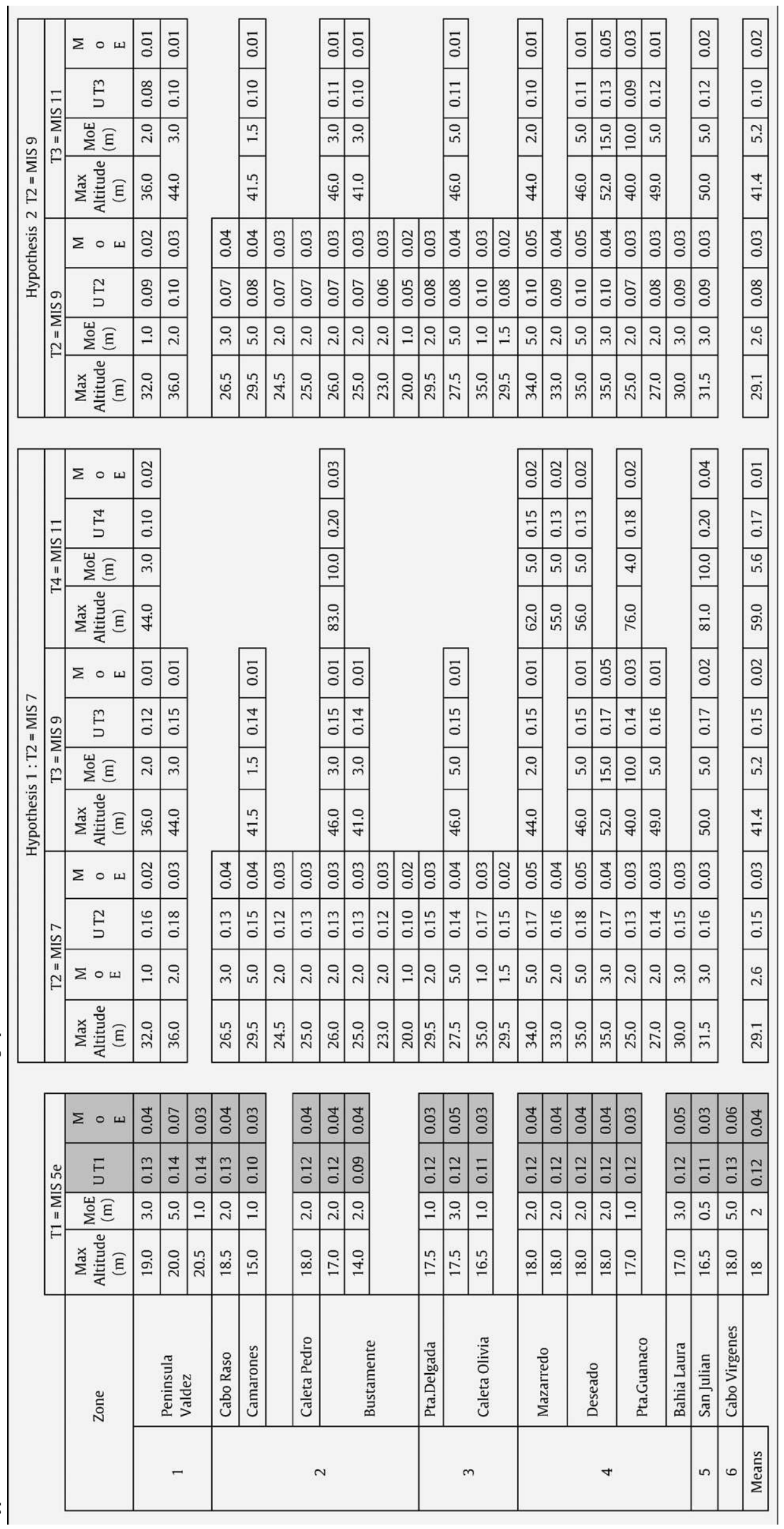


5e). Given i) the uncertainty in Holocene sea level, which does not to fit recent models of the global process of glacial isostatic adjustments (i.e. Rostami et al., 2000), and ii) the margin of error associated to elevation measurement, which is relatively important for low standing marine terrace (e.g. Monti, 2002), we do not calculate the uplift rate for the Holocene and instead concentrate on the Pleistocene period.

The Last Interglacial Maximum shorelines are well represented all over the Patagonian coast. The resulting uplift rates (Table 3, Fig. 10) are nearly uniform all over the studied area (six zones) and have an average value of $0.12 \pm 0.04 \mathrm{~mm} / \mathrm{yr}$. The coast of Tierra del Fuego is seemingly uplifting at a lower rate $(\sim 0.10 \mathrm{~mm} / \mathrm{yr})$. The terraces associated to MIS 5e are frequently compound (see Fig. 1B). We suggest that that the lower terrace (i.e. T1') could have been carved during a latter phase of MIS 5 (i.e. MIS $5 \mathrm{a}$, or $5 \mathrm{c}$ ).
Once the correlation of the two well marked last interglacials (i.e. MIS 5e and MIS 1) with paleoshores reaching 8-10 $\mathrm{m}$ and $16-20 \mathrm{~m}$ is done, two morpho-chronological scenarios can be envisaged. In other words the T2 shoreline can be correlated either to MIS 7 or to MIS 9 (Fig. 10, Table 3). The first hypothesis (i.e. T2= MIS 7) takes into account previous dating of Quaternary coastal deposits in Peninsula Valdez, Bahía Camarones, Bahía Bustamente, Caleta Olivia and implies a nearly constant uplift rate through time (Table 3 ). The second hypothesis does not integrate the observation and dating of depositional paleoshore correlated to MIS 7 and implies a slight increase in uplift rates during the last interglacial. Non-steady coastal uplift rates have been evidenced in Chile (Saillard et al., 2009) on a coast located in front of a subduction zone. The Patagonian coastal morphologies are present on a passive margin and have been compared to sequences found along the northern coasts of the

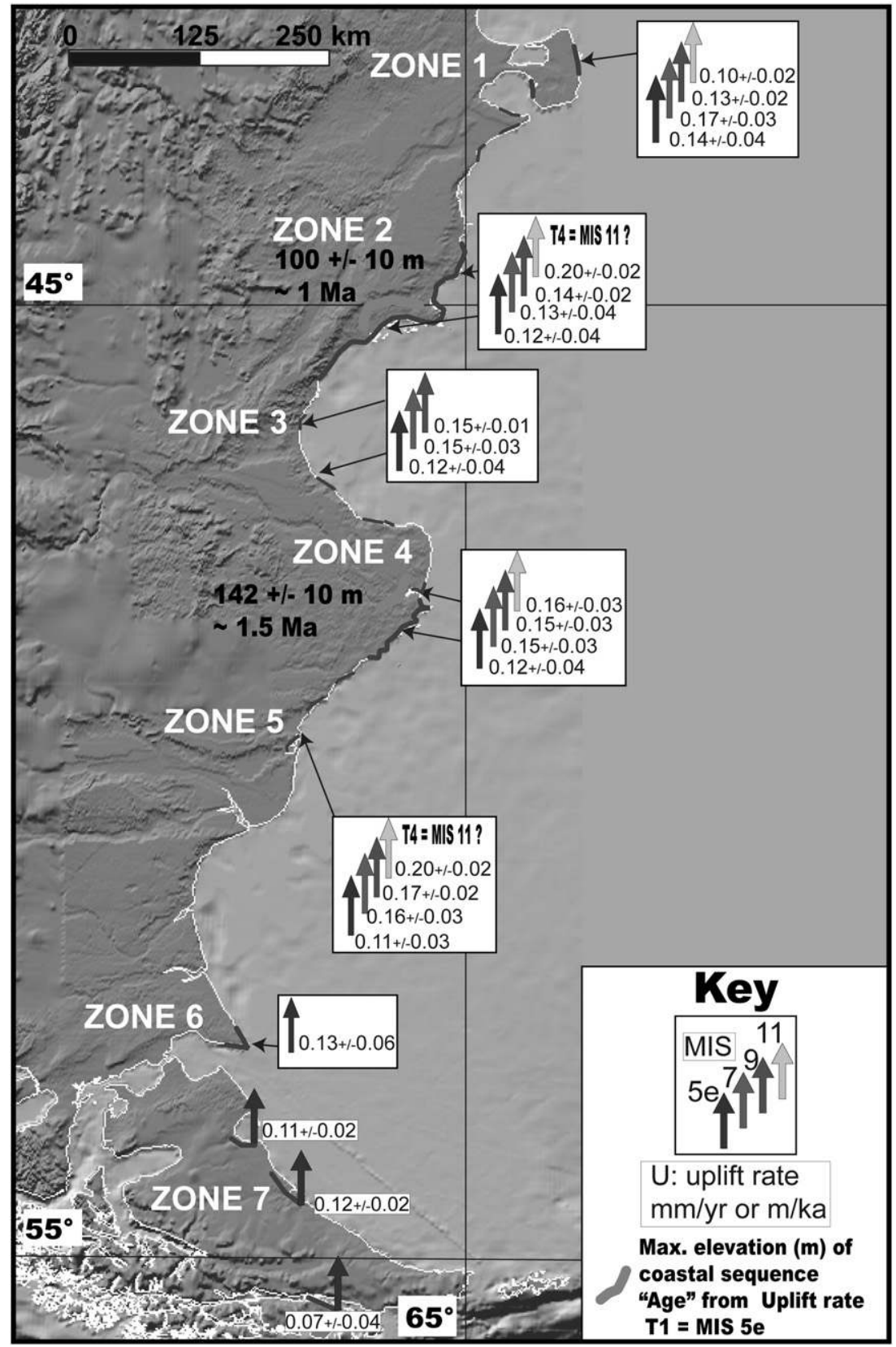

Fig. 10. Pleistocene uplift of eastern Patagonia since MIS 11. 


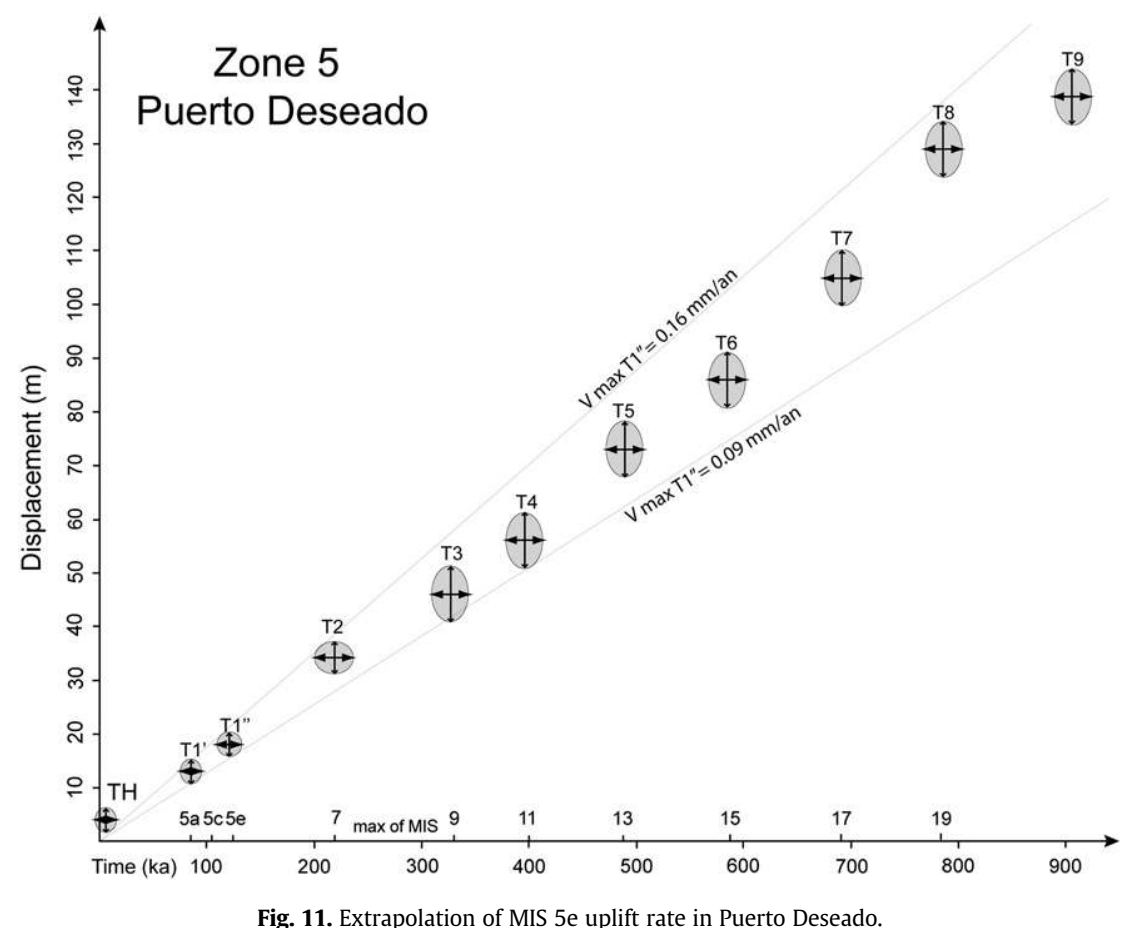

Fig. 11. Extrapolation of MIS 5e uplift rate in Puerto Deseado.

South China Sea (Pedoja et al., 2008a,b) also located on a passive margin (see discussion in Pedoja et al., 2008a,b, for comparison with other passive margins). Because in a tectonically rather quiet area like Patagonia, we do not foresee any reason for time-dependent uplift rates, we therefore opt for the most conservative first scenario and suggest that it is the most plausible hypothesis. In other words, we propose that uplift in eastern Patagonia remained constant through time since MIS 11 ( $400 \pm 20 \mathrm{ka}$ ) and that morphologies correlated to MIS 7 highstands are present on the coast (Figs. 10 and 11). Based on an extrapolation of the regional (steady) uplift rates for MIS 5e $(\sim 0.12 \pm 0.04 \mathrm{~mm} / \mathrm{yr})$, we surmise that the formation of the undated terrace sequence in Puerto Deseado (zone 5), including 5 shoreline angles up to $142 \pm 10$, encompassed the period between about $1 \mathrm{Ma}$ ago and MIS 13 ( 480 ka) (Fig. 11).

\section{Discussion: uplift of the eastern coast of South America}

Along the eastern coast of South America, Quaternary coastal sequences are identified in 34 sites (Fig. 12) in Southern Chile (1 site), Argentina (23 sites), Uruguay (2 sites), Brazil ( 8 sites, but some of them extremely large), French Guyana (1 large site) (see Table 4 for detailed references). The area where Quaternary coastal sequences are found encompasses the majority of the eastern South American coast (Table 4, Fig. 12), with the exception of estuaries and deltas contexts (i.e. Río de la Plata, Amazon).

Altitudes of MIS 5e shorelines ( 34 sites) range from $-7 \pm 2 \mathrm{~m}$ (site 23 ) to $20 \pm 1 \mathrm{~m}$ (sites 17,18 , and 32) with a mean of $13 \mathrm{~m}$. These results imply apparent uplift rates ranging from $-0.08 \pm 0.02 \mathrm{~mm} / \mathrm{yr}$ to $0.12 \pm 0.02 \mathrm{~mm} / \mathrm{yr}$ with a mean of $0.08 \pm 0.03 \mathrm{~mm} / \mathrm{yr}$. Explaining the generalized uplift of the coast of South America likely requires an analysis at a larger-scale that involves the dynamics of the Atlantic Ocean. Russo and Silver (1996) and Silver et al. (1998) relate the growth of the Andes to the dynamics of the Tethys and Atlantic Ocean by an increase in the mean compression of the South American continent in response to an acceleration of its westward drift. A similar process could occur along the passive margin of South America. Indeed, analogue experiments by Leroy et al. (2004) that illustrate the behavior of passive margins show that increasing horizontal stresses may be accompanied by thrusting of the continental margin. The associated crustal thickening induces uplift along the coast. Although their model is performed at a larger scale and matches data on a longer time scale, their finding may support our observations of Quaternary continental-scale generalized uplift. At this stage, it remains our preferred explanation.

But the data bears more important information: the uplift rate shows latitudinal variation. This, in turns, illustrates that at the scale of the Atlantic coast of South America, local sea level curves depart from global curves. Because of its fairly simple geodynamic setting, this example provides a excellent means to evaluate the causes of such variations. We observe a general tendency to increasing uplift rates from Brazil to Patagonia (Fig. 13). Outliers are located in the mouth of the Río de la Plata. This is of no surprise because subsidence or low uplift rates can be attributed to the sedimentation load (CARP, 1989) and associated isostatic compensation. Excepting the data in this area, a single outlier remains to the north of Recife, at the easternmost tip of South America, for which we found no explanation. The remaining data points follow the tendency of increasing uplift rates towards the south. The dispersion is a little too large to give credence in automated regression profiles. The southward increase could be described by a linear trend from $\sim 0.05 \mathrm{~mm} / \mathrm{yr}$ to the north to $\sim 0.12 \mathrm{~mm} / \mathrm{yr}$ in Patagonia. Alternatively, the signal can be decomposed into the northern part (from $0^{\circ}$ to $42^{\circ} \mathrm{S}$ ), where the mean uplift rate is $\sim 0.06 \mathrm{~mm} / \mathrm{yr}$ and the southern part, namely Patagonia, where the mean uplift rate is as high as $\sim 0.12 \mathrm{~mm} / \mathrm{yr}$. This suggests that the coast of Patagonia is uplifting $\sim 0.06 \mathrm{~mm} / \mathrm{yr}$ faster than the rest of the coast of South America. The transition lies approximately at the latitude (or a little north of) the triple junction along the Chilean trench that stands at the intersection of the Antarctica, Nazca and South America plates (Fig. 12). This finding has to be compared with the results of Guillaume et al. (2009), who argue on the basis of geomorphological arguments that the topography of Patagonia recorded different stages of trench-parallel regional tilting during the northward migration of the triple junction along the coast of Chile 


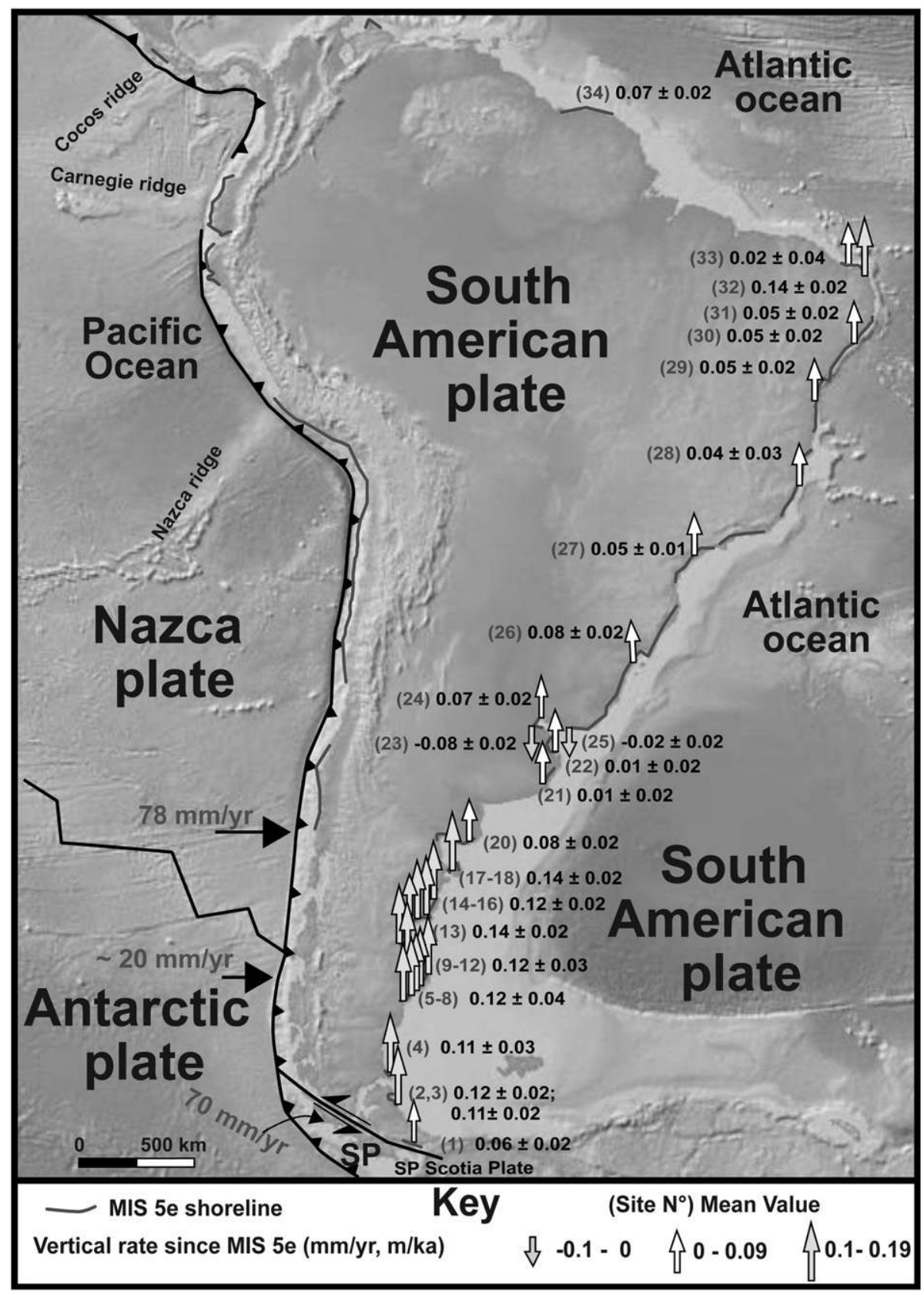

Fig. 12. Pleistocene uplift along the whole southeast American coast.

(Fig. 14). Because the dynamics of subduction that accompanies the embryonic Antarctica slab is much less vigorous than the dynamics of the Nazca subduction, the forces exerted by the mantle flow above the Antarctica slab are smaller in magnitude than those induced above the Nazca slab. The dynamic deflection of the topography in the overriding plate, i.e. South America, responds accordingly: at a given place, the magnitude of the depression gets smaller as the mild subduction of the Antarctica slab replaces that of the Nazca slab. With the triple junction migrating to the north, this process affects regions located more and more to the north. On the basis of simple isoviscous models, Guillaume et al. (2009) suggest that the cumulated dynamic rebound of the topography in Patagonia, that accompanies the decrease in the vigour of the underlying mantle flow, reaches several hundred meters along the Patagonian Atlantic coastline over the last 14 Myr.
Although the resolution of the models does not allow for a straightforward comparison to our results that only span the last glacial cycle, we emphasize that the observed latitudinal variations in uplift rates are at least compatible with their interpretation. More accurate models would be difficult to perform, not for the technical challenge but for the nature of the underlying mantle which is insufficiently known (viscosity and densities in particular). We nevertheless propose that the mechanism described by Guillaume et al. (2009) is the best candidate to explain our observations, i.e. the time-varying dynamic topography is responsible for the observed latitudinal dependence in uplift rates, making Patagonia uplifting faster than the portion of the South American coastline north of Patagonia. Note that this uplift reveals a tendency to restore isostatic equilibrium of Patagonia rather than showing an anomalous situation, while the northern counterpart remains 
Table 4

Elevation of MIS 5e marine terrace along the Eastern South America coast and implied uplift rates.

\begin{tabular}{|c|c|c|c|c|c|c|c|}
\hline$n^{\circ}$ & Country & Zone & Lat 1 & Lon 1 & Lat2 & Lon 2 & Name \\
\hline 1 & Chile & $\mathrm{S}$ & $55^{\circ} \mathrm{S}$ & $67^{\circ} 15^{\prime} \mathrm{W}$ & $55^{\circ} \mathrm{S}$ & $67^{\circ} 15^{\prime} \mathrm{W}$ & Corrales Viejos \\
\hline 2 & Argentina & La Sara-Viamonte & $53^{\circ} 25^{\prime} 48.56^{\prime \prime} \mathrm{S}$ & $68^{\circ} 4^{\prime} 36.44^{\prime \prime} \mathrm{W}$ & $54^{\circ} 1^{\prime} 3.93^{\prime \prime} \mathrm{S}$ & $67^{\circ} 20^{\prime} 36.74^{\prime \prime} \mathrm{W}$ & La Sara-Viamonte \\
\hline 3 & & Bahia San Sebastian & $52^{\circ} 58^{\prime} 42.44^{\prime \prime} \mathrm{S}$ & $68^{\circ} 17^{\prime} 0.67^{\prime \prime} \mathrm{W}$ & $53^{\circ} 38^{\prime} 28.01^{\prime \prime} \mathrm{S}$ & $67^{\circ} 53^{\prime} 11.48^{\prime \prime} \mathrm{W}$ & Bahia San Sebastian \\
\hline 4 & & Cabo Virgenes & $52^{\circ} 20^{\prime} \mathrm{S}$ & $68^{\circ} 22^{\prime} \mathrm{W}$ & $52^{\circ} 20^{\prime} \mathrm{S}$ & $68^{\circ} 22^{\prime} \mathrm{W}$ & Cabo Virgenes \\
\hline 5 & & San Julian & $49^{\circ} 09^{\prime} 09.04^{\prime \prime} \mathrm{S}$ & $67^{\circ} 38^{\prime} 05.80^{\prime \prime} \mathrm{W}$ & $49^{\circ} 25^{\prime} 59.21^{\prime \prime} \mathrm{S}$ & $67^{\circ} 40^{\prime \prime} 28.62^{\prime \prime \prime} \mathrm{W}$ & San Julian \\
\hline 6 & & Peninsula Deseado & $47^{\circ} 45^{\prime} 44^{\prime \prime} \mathrm{S}$ & $65^{\circ} 53^{\prime} 51^{\prime \prime} \mathrm{W}$ & $48^{\circ} 24^{\prime} 55.65^{\prime \prime} \mathrm{S}$ & $66^{\circ} 30^{\prime} 05.56^{\prime \prime} \mathrm{W}$ & Peninsula Deseado South \\
\hline 7 & & Peninsula Deseado & $47^{\circ} 41^{\prime} 30^{\prime \prime} \mathrm{S}$ & $65^{\circ} 49^{\prime} 22.53^{\prime \prime} \mathrm{W}$ & $47^{\circ} 44^{\prime} 30.40^{\prime \prime} \mathrm{S}$ & $65^{\circ} 58^{\prime} 54.69^{\prime \prime} \mathrm{W}$ & Puerto Deseado \\
\hline 8 & & Peninsula Deseado & $47^{\circ} 01^{\prime} 50^{\prime \prime} \mathrm{S}$ & $66^{\circ} 40^{\prime} \mathrm{W}$ & $47^{\circ} 01^{\prime} 50^{\prime \prime} \mathrm{S}$ & $66^{\circ} 40^{\prime} \mathrm{W}$ & Mazarredo \\
\hline 9 & & San Jorge Gulf & $46^{\circ} 28^{\prime} 34.58^{\prime \prime} \mathrm{S}$ & $67^{\circ} 29^{\prime} 38.19^{\prime \prime} \mathrm{W}$ & $49^{\circ} 39^{\prime} 01.65^{\prime \prime} \mathrm{S}$ & $67^{\circ} 15^{\prime} 18.30^{\prime \prime} \mathrm{W}$ & Caleta Olivia \\
\hline 10 & & San Jorge Gulf & $46^{\circ} 03^{\prime} 57.27^{\prime \prime S}$ & $67^{\circ} 36^{\prime} 55.86^{\prime \prime} \mathrm{W}$ & $46^{\circ} 03^{\prime} 57.27^{\prime \prime S}$ & $67^{\circ} 36^{\prime} 55.86^{\prime \prime} \mathrm{W}$ & Punta Delgada \\
\hline 11 & & Bahia Bustamente & $45^{\circ} 13^{\prime} 23.53^{\prime \prime} S$ & $66^{\circ} 31^{\prime} 10.14^{\prime \prime} \mathrm{W}$ & $45^{\circ} 13^{\prime} 55.53^{\prime \prime} \mathrm{S}$ & $66^{\circ} 50^{\prime} 07.11^{\prime \prime} \mathrm{W}$ & Punta Artizizabal \\
\hline 12 & & Bahia Bustamante & $45^{\circ} 05^{\prime} 51.93^{\prime \prime} \mathrm{S}$ & $66^{\circ} 31^{\prime} 05.06^{\prime \prime} \mathrm{W}$ & $45^{\circ} 09^{\prime} 28.40^{\prime \prime} \mathrm{S}$ & $60^{\circ} 34^{\prime} 59.54^{\prime \prime} \mathrm{W}$ & Bustamente South \\
\hline 13 & & Bahia Bustamante & $45^{\circ} 03^{\prime} \mathrm{S}$ & $66^{\circ} 19^{\prime} \mathrm{W}$ & $45^{\circ} 05^{\prime} 51.93^{\prime \prime} \mathrm{S}$ & $66^{\circ} 31^{\prime} 05.06^{\prime \prime} \mathrm{W}$ & Bustamente North \\
\hline 14 & & Cabo dos Bahias & $44^{\circ} 53^{\prime} 07.79^{\prime \prime} \mathrm{S}$ & $65^{\circ} 37^{\prime} 38.19^{\prime \prime} \mathrm{W}$ & $44^{\circ} 53^{\prime} 07.79^{\prime \prime} \mathrm{S}$ & $65^{\circ} 37^{\prime} 38.19^{\prime \prime} \mathrm{W}$ & Caleta Pedro \\
\hline 15 & & Bahia Camarones & $44^{\circ} 43^{\prime} 41.65^{\prime \prime} \mathrm{S}$ & $65^{\circ} 41^{\prime} 40.68^{\prime \prime} \mathrm{W}$ & $44^{\circ} 52^{\prime} 11.86^{\prime \prime} \mathrm{S}$ & $65^{\circ} 42^{\prime} 49.43^{\prime \prime} \mathrm{W}$ & Camarones town \\
\hline 16 & & Bahia Camarones & $44^{\circ} 11^{\prime} 35.18^{\prime \prime S}$ & $65^{\circ} 18^{\prime} 39.41^{\prime \prime} \mathrm{W}$ & $44^{\circ} 23^{\prime} 55^{\prime \prime} \mathrm{S}$ & $65^{\circ} 15^{\prime} 58.73^{\prime \prime} \mathrm{W}$ & Cabo Raso \\
\hline 17 & & Peninsula Valdez & $42^{\circ} 35^{\prime} \mathrm{S}$ & $64^{\circ} 18^{\prime} 13^{\prime \prime} \mathrm{W}$ & $42^{\circ} 35^{\prime} \mathrm{S}$ & $64^{\circ} 18^{\prime} 13^{\prime \prime} \mathrm{W}$ & Puerto Piramides \\
\hline 18 & & Peninsula Valdez & $42^{\circ} 09^{\prime} 44.95^{\prime \prime} \mathrm{S}$ & $63^{\circ} 42^{\prime} 16.10^{\prime \prime} \mathrm{W}$ & $42^{\circ} 30^{\prime} 40^{\prime \prime} \mathrm{S}$ & $63^{\circ} 35^{\prime} 56.71^{\prime \prime} \mathrm{W}$ & Caleta Valdez \\
\hline 19 & & San Antonio Oeste & $40^{\circ} 42^{\prime} 45.89^{\prime \prime} \mathrm{S}$ & $65^{\circ} 2^{\prime} 4.50^{\prime \prime} \mathrm{W}$ & $40^{\circ} 44^{\prime} 28.60^{\prime \prime} \mathrm{S}$ & $64^{\circ} 44^{\prime} 15.67^{\prime \prime} \mathrm{W}$ & San Antonio Oeste \\
\hline 20 & & San Blas & $40^{\circ} 31^{\prime} 43.21^{\prime \prime} \mathrm{S}$ & $62^{\circ} 18^{\prime} 43.11^{\prime \prime} \mathrm{W}$ & $40^{\circ} 41^{\prime} 56.36^{\prime \prime} \mathrm{S}$ & $62^{\circ} 14^{\prime} 15.10^{\prime \prime} \mathrm{W}$ & San Blas \\
\hline 21 & & Central & $37^{\circ} 43^{\prime} 55.45^{\prime \prime} \mathrm{S}$ & $57^{\circ} 24^{\prime} 54.09^{\prime \prime} \mathrm{W}$ & $36^{\circ} 26^{\prime} 22.49^{\prime \prime} \mathrm{S}$ & $56^{\circ} 39^{\prime} 45.47^{\prime \prime} \mathrm{W}$ & Mar Chiquita \\
\hline 22 & & $\mathrm{~N}$ & $35^{\circ} 28^{\prime} 1.68^{\prime \prime} \mathrm{S}$ & $57^{\circ} 7^{\prime} 15.49^{\prime \prime} \mathrm{W}$ & $36^{\circ} 20^{\prime} 33.62^{\prime \prime} \mathrm{S}$ & $56^{\circ} 47^{\prime} 37.16^{\prime \prime} \mathrm{W}$ & Samborombon \\
\hline 23 & & $\mathrm{~N}$ & $34^{\circ} 28^{\prime} 22.10^{\prime \prime} \mathrm{S}$ & $58^{\circ} 54^{\prime} 39.54^{\prime \prime} \mathrm{W}$ & $34^{\circ} 28^{\prime} 22.10^{\prime \prime} \mathrm{S}$ & $58^{\circ} 54^{\prime} 39.54^{\prime \prime} \mathrm{W}$ & Pilar \\
\hline 24 & Uruguay & $\mathrm{E}$ & $33^{\circ} 53^{\prime} 30.53^{\prime \prime} \mathrm{S}$ & $58^{\circ} 24^{\prime} 38.35^{\prime \prime} \mathrm{w}$ & $33^{\circ} 53^{\prime} 30.53^{\prime \prime} \mathrm{S}$ & $58^{\circ} 24^{\prime} 38.35^{\prime \prime} \mathrm{w}$ & Nueva Palmira \\
\hline 25 & & $\mathrm{E}$ & $33^{\circ} 54^{\prime} 11.71^{\prime \prime} \mathrm{S}$ & $53^{\circ} 30^{\prime} 5.40^{\prime \prime} \mathrm{W}$ & $33^{\circ} 54^{\prime} 11.71^{\prime \prime} \mathrm{S}$ & $53^{\circ} 30^{\prime} 5.40^{\prime \prime} \mathrm{W}$ & La Coronilla \\
\hline 26 & Brazil & $\mathrm{S}$ & $29^{\circ} 23^{\prime} 39.19^{\prime \prime} \mathrm{S}$ & $49^{\circ} 49^{\prime} 21.85^{\prime \prime} \mathrm{W}$ & $33^{\circ} 46^{\prime} 11.62^{\prime \prime} \mathrm{S}$ & $53^{\circ} 19^{\prime} 33.20^{\prime \prime} \mathrm{W}$ & Patos/Rio Grande do Sul \\
\hline 27 & & S Central & $22^{\circ} 55^{\prime} 51.44^{\prime \prime} \mathrm{S}$ & $44^{\circ} 20^{\prime} 40.31^{\prime \prime} \mathrm{W}$ & $26^{\circ} 12^{\prime} 1.58^{\prime \prime} \mathrm{S}$ & $48^{\circ} 38^{\prime} 11.52^{\prime \prime} \mathrm{W}$ & Sao Paulo \\
\hline 28 & & S Central & $7^{\circ} 52^{\prime} 25.56^{\prime \prime} \mathrm{S}$ & $34^{\circ} 50^{\prime} 19.87^{\prime \prime} \mathrm{W}$ & $27^{\circ} 35^{\prime} 31.06^{\prime \prime} \mathrm{S}$ & $48^{\circ} 34^{\prime} 9.66^{\prime \prime} \mathrm{W}$ & East Brazil 1-4 \\
\hline 29 & & Central & $10^{\circ} 26^{\prime} 37.80^{\prime \prime} \mathrm{S}$ & $36^{\circ} 22^{\prime} 11.24^{\prime \prime} \mathrm{W}$ & $10^{\circ} 26^{\prime} 37.80^{\prime \prime} \mathrm{S}$ & $36^{\circ} 22^{\prime} 11.24^{\prime \prime} \mathrm{W}$ & Jequia \\
\hline 30 & & Central & $9^{\circ} 25^{\prime} 44.01^{\prime \prime} \mathrm{S}$ & $35^{\circ} 30^{\prime} 46.40^{\prime \prime} \mathrm{W}$ & $9^{\circ} 52^{\prime} 8.69^{\prime \prime} \mathrm{S}$ & $35^{\circ} 54^{\prime} 47.05^{\prime \prime} \mathrm{W}$ & Maceio \\
\hline 31 & & Central & $9^{\circ} 5^{\prime} 18.74^{\prime \prime} \mathrm{S}$ & $35^{\circ} 14^{\prime} 51.36^{\prime \prime} \mathrm{W}$ & $9^{\circ} 19^{\prime} 30.31^{\prime \prime S}$ & $35^{\circ} 24^{\prime} 26.65^{\prime \prime} \mathrm{W}$ & Alagoas \\
\hline 32 & & Central E & $5^{\circ} 11^{\prime} 45.85^{\prime \prime} \mathrm{S}$ & $35^{\circ} 27^{\prime} 53.17^{\prime \prime} \mathrm{W}$ & $5^{\circ} 19^{\prime} 23.66^{\prime \prime} \mathrm{S}$ & $35^{\circ} 21^{\prime} 43.19^{\prime \prime} \mathrm{W}$ & Zumbi North \\
\hline 33 & & Central E & $5^{\circ} 5^{\prime} 16.65^{\prime \prime} \mathrm{S}$ & $36^{\circ} 3^{\prime} 39.16^{\prime \prime} \mathrm{W}$ & $5^{\circ} 11^{\prime} 45.85^{\prime \prime} \mathrm{S}$ & $35^{\circ} 27^{\prime} 53.17^{\prime \prime} \mathrm{W}$ & Sao Bento - Touros \\
\hline 34 & France & Guyana & $5^{\circ} 33^{\prime} 4.54^{\prime \prime} \mathrm{N}$ & $53^{\circ} 27^{\prime} 33.82^{\prime \prime} \mathrm{W}$ & $4^{\circ} 56^{\prime} 56.09^{\prime \prime} \mathrm{N}$ & $52^{\circ} 18^{\prime} 29.65^{\prime \prime} \mathrm{W}$ & French Guyana \\
\hline
\end{tabular}

dynamically deflected. Our observation suggests that the transition zone is located at $\sim 42-43^{\circ} \mathrm{S}$, which is 300 to $400 \mathrm{~km}$ to the north of the model predicted transition proposed by Guillaume et al. (2009).
Again, the poor resolution of the model and the different time and space scales between the model and observations make direct comparisons hazardous. This minor discrepancy could be explained 


\begin{tabular}{|c|c|c|c|c|c|c|c|}
\hline $\begin{array}{l}\text { Elevation } \\
\text { of MIS } 5 \mathrm{e}\end{array}$ & MoE & Shoreline type & $\begin{array}{l}\text { Eustasy-corrected } \\
\text { vertical rate } \mathrm{Vc}(\mathrm{mm} / \mathrm{yr})\end{array}$ & MoE & $\begin{array}{l}\text { Max. duration } \\
\text { of geol. record }\end{array}$ & References & Confidence \\
\hline 10 & 1 & marine terrace & 0.06 & 0.02 & * & $\begin{array}{l}\text { (Ortiz-Troncoso, 1979; Bujalesky, 2007; } \\
\text { Rabassa et al., 2008) }\end{array}$ & 4 \\
\hline 18 & 1 & beach deposits & 0.12 & 0.02 & > MIS 11 & (Bujalesky and Isla, 2006; Bujalesky, 2007) & 5 \\
\hline 16 & 1 & $\begin{array}{l}\text { marine terrace / beach } \\
\text { ridge / cheniers? }\end{array}$ & 0.11 & 0.02 & Since MIS 5e ? & $\begin{array}{l}\text { (Rutter et al., 1989; González Bonorino } \\
\text { et al., 1999; Vilas et al., 1999) }\end{array}$ & \\
\hline 17 & 5 & marine terrace / beach ridge & 0.11 & 0.05 & Since MIS 5e? & This study; Pedoja et al., 2008b & 2 \\
\hline 16.5 & 0.5 & marine terrace / beach ridge & 0.11 & 0.03 & Since $0.7 \mathrm{Ma}$ & $\begin{array}{l}\text { This study; Pedoja et al., 2008b; Rostami et al., 2000; } \\
\text { Schellmann and Radtke, 2000; Feruglio, } 1950\end{array}$ & 4 \\
\hline 17 & 3 & $\begin{array}{l}\text { marine terrace / beach } \\
\text { ridge / notch }\end{array}$ & 0.12 & 0.03 & Since $0.7 \mathrm{Ma}$ & This study; Pedoja et al., 2008b; Feruglio, 1950 & 5 \\
\hline 18 & 2 & marine terrace / beach ridge & 0.12 & 0.03 & Since $1.5 \mathrm{Ma}$ & $\begin{array}{l}\text { This study; Pedoja et al., 2008b; Rutter et al., 1989, } \\
\text { 1990; Codignotto et al., 1988; Feruglio, } 1950\end{array}$ & 5 \\
\hline 18 & 2 & marine terrace / beach ridge & 0.12 & 0.03 & $\begin{array}{l}\text { Since MIS } 11 \\
\text { and/or } 14\end{array}$ & $\begin{array}{l}\text { This study; Aguirre et al., 2009; Pedoja et al., 2008b; } \\
\text { Rostami et al., 2000; Schellmann and Radtke, 2000; } \\
\text { Codignotto et al., 1992; Feruglio, 1933, } 1950\end{array}$ & 5 \\
\hline 17.5 & 3 & marine terrace / beach ridge & 0.12 & 0.04 & $\begin{array}{l}\text { Since MIS } 11 \\
\text { and/or } 13\end{array}$ & $\begin{array}{l}\text { This study; Aguirre et al., 2009; Pedoja et al., 2008b; } \\
\text { Aguirre, 2003; Schellmann and Radtke, 2000, 2003; } \\
\text { Rostami et al., 2000; Feruglio, } 1950\end{array}$ & 5 \\
\hline 17.5 & 1 & marine terrace & 0.12 & 0.03 & Since MIS 9 & $\begin{array}{l}\text { This study; Pedoja et al., 2008b; Schellmann and } \\
\text { Radtke, 2003; Caldenius, } 1940\end{array}$ & 5 \\
\hline 17 & 2 & marine terrace / beach ridge & 0.12 & 0.03 & Since MIS 9 & This study; Pedoja et al., 2008b & 5 \\
\hline $14\left(\mathrm{~T} 1^{\prime} ?\right)$ & 2 & marine terrace / beach ridge & 0.09 & 0.03 & Since MIS 9 or 11 & $\begin{array}{l}\text { This study; Pedoja et al., 2008b; Sauer et al., 2007; } \\
\text { Aguirre et al., 2005; Rostami et al., 2000; Schellmann } \\
\text { and Radtke, 1997, 2000; Rutter et al., 1989; } \\
\text { Schellmann, 1998; Cionchi, 1987, 1988; Codignotto, } \\
\text { 1983; Feruglio, 1933, } 1950\end{array}$ & 5 \\
\hline 17 & 1 & marine terrace / beach ridge & 0.12 & 0.03 & Since MIS 9 or 11 & $\begin{array}{l}\text { This study; Pedoja et al., 2008b; Sauer et al., 2007; } \\
\text { Aguirre et al., 2005; Rostami et al., 2000; Schellmann } \\
\text { and Radtke, 1997, 2000; Codignotto et al., 1992; } \\
\text { Rutter et al., 1989, 1990; Schellmann, 1998; Codignotto } \\
\text { et al., 1988; Cionchi, 1987; 1988; Codignotto, } \\
\text { 1983; Feruglio, 1933, } 1950\end{array}$ & 5 \\
\hline 18 & 2 & marine terrace / beach ridge & 0.12 & 0.04 & Since MIS 9 & This study; Pedoja et al., 2008b & 5 \\
\hline 15 & 1 & marine terrace / beach ridge & 0.10 & 0.03 & Since MIS 11 & $\begin{array}{l}\text { This study; Pedoja et al., 2008b; Sauer et al., 2007; } \\
\text { Aguirre et al., 2006; Rostami et al., 2000; Schellmann } \\
\text { and Radtke, 2000; Feruglio, } 1950\end{array}$ & 5 \\
\hline 18.5 & 2 & marine terrace / beach ridge & 0.13 & 0.04 & Since MIS 9 or 11 & $\begin{array}{l}\text { This study; Pedoja et al., 2008b; Aguirre et al., 2006; } \\
\text { Feruglio, } 1950\end{array}$ & 5 \\
\hline 20 & 5 & marine terrace & 0.14 & 0.06 & Since MIS 5e & This study; Pedoja et al., 2008b; Feruglio, 1950 & 5 \\
\hline 20.5 & 1 & wave-built terrace / beach ridge & 0.14 & 0.02 & since MIS 9 & $\begin{array}{l}\text { This study; Pedoja et al., 2008b; Rostami et al., 2000; } \\
\text { Schellmann and Radtke, 2000; Rutter et al., } \\
\text { 1989, 1990; Feruglio, } 1950\end{array}$ & 5 \\
\hline 11 & 1 & wave-built terrace / beach ridge & 0.07 & 0.02 & Since MIS 5e ? & Rutter et al. (1989) & 5 \\
\hline 13 & 1 & $\begin{array}{l}\text { wave-built terrace / beach } \\
\text { ridge }\end{array}$ & 0.08 & 0.02 & Since MIS 5e ? & (Codignotto, 1987; Rutter et al., 1989) & 5 \\
\hline 4 & 1 & $\begin{array}{l}\text { wave-built terrace / beach } \\
\text { ridge / coastal deposits }\end{array}$ & 0.01 & 0.02 & MIS 5 & (Aguirre and Whatley, 1995; Aguirre et al., 1995) & 3 \\
\hline 4.5 & 1.5 & $\begin{array}{l}\text { wave-built terrace / beach } \\
\text { ridge / coastal deposits }\end{array}$ & 0.01 & 0.02 & MIS 5 & $\begin{array}{l}\text { (Codignotto and Aguirre, 1993; Aguirre and } \\
\text { Whatley, 1995; Aguirre et al., 1995; Aguirre and } \\
\text { Whatley, 1996; Radtke and Schellmann, 1996) }\end{array}$ & 3 \\
\hline-7 & 2 & coastal deposits & -0.08 & 0.02 & * & (Fucks et al., 2005; Tricart et al., 1972) & 2 \\
\hline 12 & 2 & coastal deposits & 0.07 & 0.03 & MIS 5 & (Martínez et al., 2001; Tricart et al., 1972) & 1 \\
\hline 0 & 1 & coastal deposits & -0.02 & 0.02 & MIS 5 & (Martínez et al., 2001) & 1 \\
\hline 13 & 1 & $\begin{array}{l}\text { marine terrace / beach ridge / } \\
\text { coastal deposits }\end{array}$ & 0.08 & 0.02 & MIS 5 & (Tomazelli and Dillenburg, 2007; Barreto et al., 2002) & 4 \\
\hline 9.5 & 0.5 & $\begin{array}{l}\text { marine terrace / beach ridge / } \\
\text { coastal deposits }\end{array}$ & 0.05 & 0.01 & MIS 5e & $\begin{array}{l}\text { (Martin and Suguio, 1976; Martin et al., 1979; } \\
\text { Bernat et al., 1983; Martin et al., 1988,1996) }\end{array}$ & 4 \\
\hline 8 & 2 & $\begin{array}{l}\text { marine terrace / beach ridge / } \\
\text { coastal deposits }\end{array}$ & 0.04 & 0.03 & MIS 5e & (Bernat et al., 1983; Martin et al., 1988,1996) & 4 \\
\hline 9 & 1 & $\begin{array}{l}\text { marine terrace / beach ridge / } \\
\text { coastal deposits }\end{array}$ & 0.05 & 0.02 & MIS 5 & (Barbosa et al., 1986; Martin et al., 1988,1996) & 4 \\
\hline 9 & 1 & $\begin{array}{l}\text { marine terrace / beach ridge / } \\
\text { coastal deposits }\end{array}$ & 0.05 & 0.02 & MIS 5 & (Barbosa et al., 1986; Martin et al., 1988,1996) & 4 \\
\hline 9 & 1 & $\begin{array}{l}\text { marine terrace / beach ridge / } \\
\text { coastal deposits }\end{array}$ & 0.05 & 0.02 & MIS 5 & $\begin{array}{l}\text { (King, 1956; Bernat et al., 1983; Barbosa et al., 1986; } \\
\text { Martin et al., 1988,1996) }\end{array}$ & 4 \\
\hline 20 & 1 & marine terrace & 0.14 & 0.02 & MIS 5e & (Tatumi et al., 2003; Barreto et al., 2002) & 3 \\
\hline 6 & 4 & marine terrace & 0.02 & 0.04 & MIS 5e & (Barreto et al., 2002; Tatumi et al., 2003) & 3 \\
\hline 11 & 1 & coastal deposits & 0.07 & 0.02 & * & Boyé (1959) & 2 \\
\hline
\end{tabular}

by a spatially variable rheology of the South American plate. Because the time scales are relatively short, the restoration of isostasy in the South American plate may involve elasticity. The elastic thickness of the plate probably changes between Patagonia and the Brazilian shield (e.g. Tassara et al., 2007), and the transition between the two units largely corresponds to the transition 


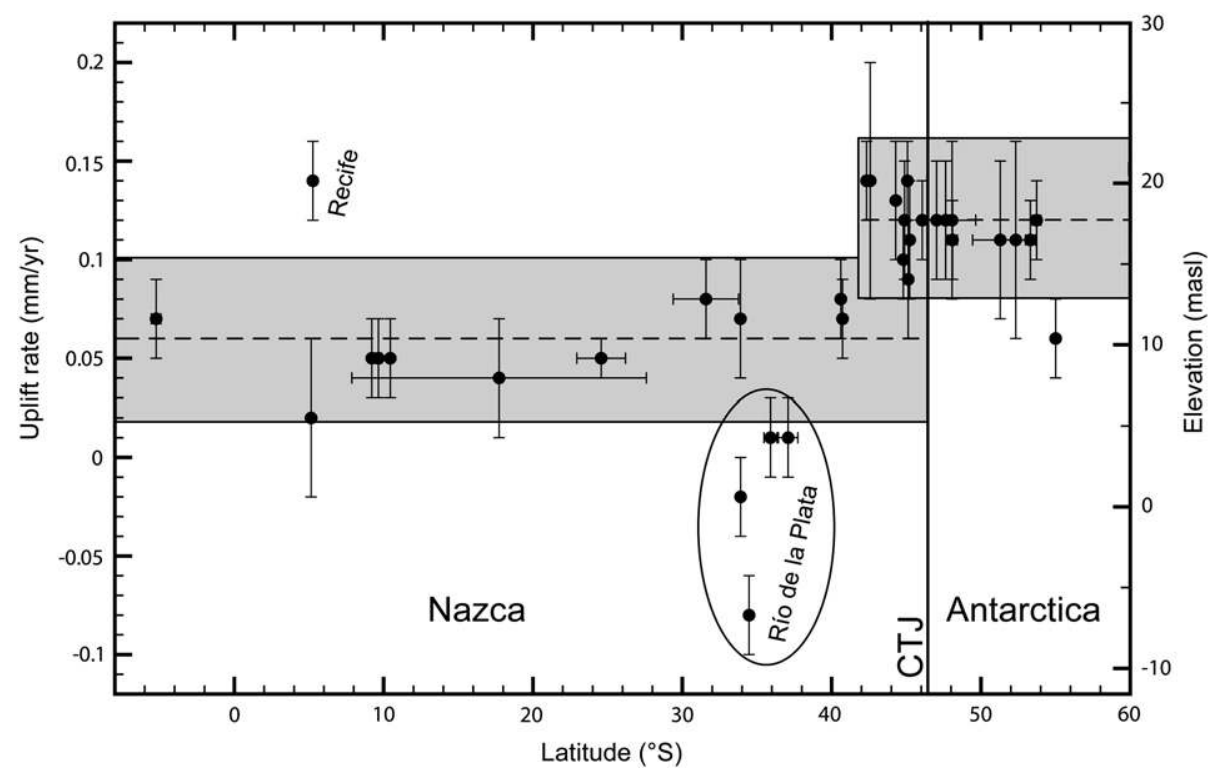

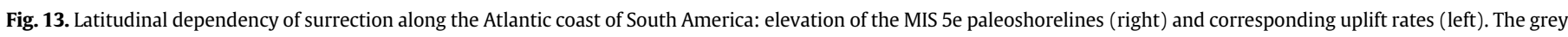

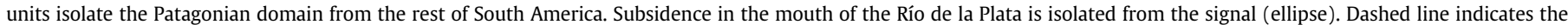
latitude of the triple junction along the Pacific active margin.
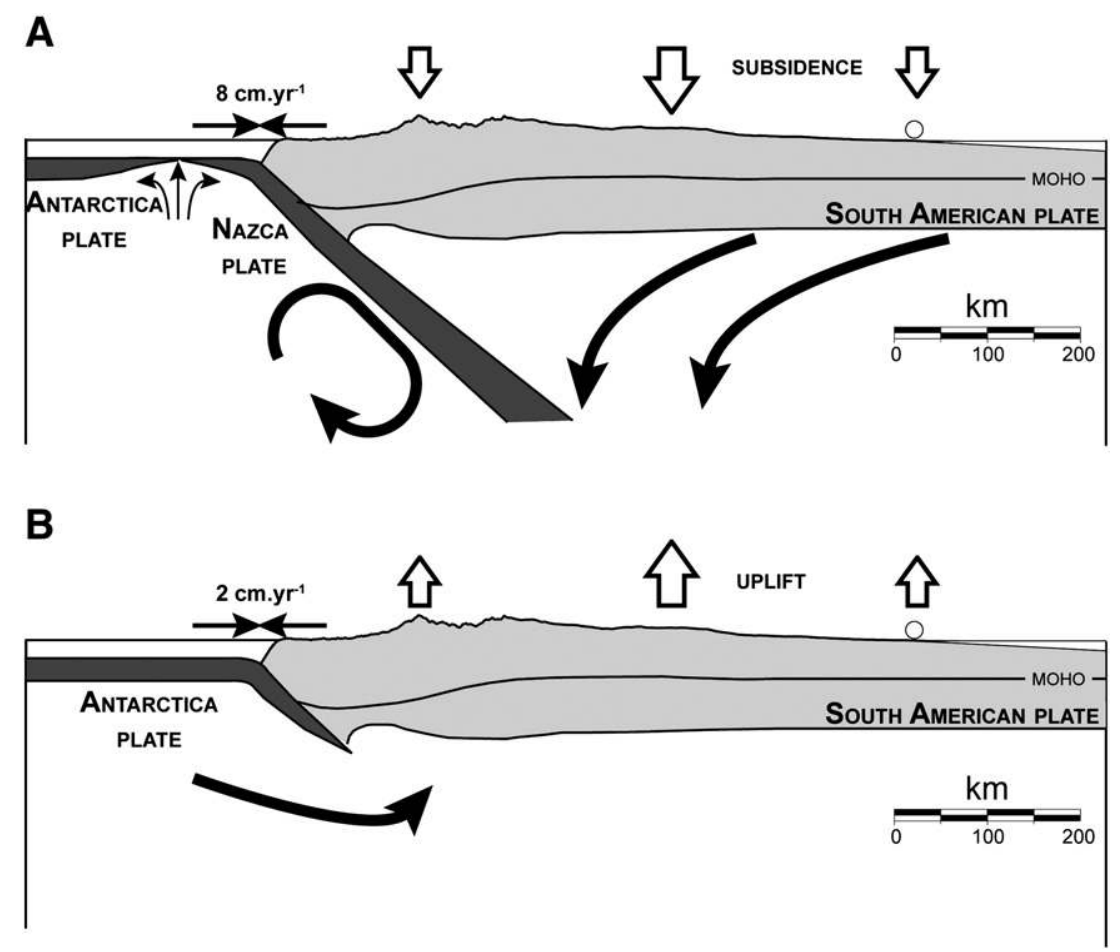

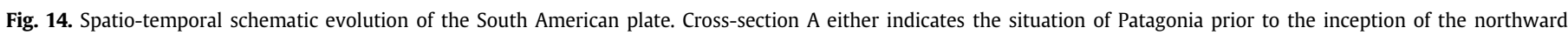

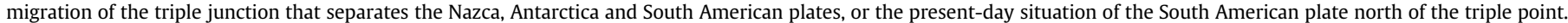
Section B shows the present-day situation of Patagonia.

Modified from Guillaume et al. (2009) by permission of American Geophysical Union, copyright 2009 AGU.

between the fast uplift rates of Patagonia and the lower rates of the rest of the Atlantic coast.

\section{Conclusions}

We have realized an extensive cartography of the Quaternary coastal sequence of eastern Patagonia. Based on previous dating works, we proposed a chrono-stratigraphical interpretation of the Patagonian sequences and, through extrapolation of MIS 5e uplift, estimated the mean uplift rate since MIS 11 ( 400 ka), $(0.12 \pm 0.04 \mathrm{~mm} / \mathrm{yr})$. After a comparison with other Quaternary coastal sequences of eastern South America we proposed that the enhanced uplift along the eastern Patagonian coast, that interested Darwin during his journey around South America on the Beagle, could originate from the subduction of the Chile ridge and the associated dynamic uplift.

Supplementary materials related to this article can be found online at doi:10.1016/j.geomorph.2010.08.003. 


\section{References}

Aguirre, M.L., 2003. Late Pleistocene and Holocene palaeoenvironments in Golfo San Jorge, Patagonia: molluscan evidence. Marine Geology 194, 3-30.

Aguirre, M.L., Whatley, R.C., 1995. Late Quaternary marginal marine deposits and palaeoenvironments from northeastern Buenos Aires Province, Argentina: a review. Quaternary Science Reviews 14, 223-254.

Aguirre, M.L., Whatley, R.C., 1996. Reply to comment of Drs U. Radtke and G. Schellmann on the paper by Aguirre, M.L. and Whatley, R.C. (1995). Late quaternary marginal marine deposits and palaeoenvironments from Northeastern Buenos Aires Province, Argentina: a review. Quaternary science reviews, 14, 223-254. Quaternary Science Reviews 15, 1063-1064.

Aguirre, M.L., Bowen, D.Q., Sykes, G.A., Whatley, R.C., 1995. A provisional aminostratigraphical framework for late Quaternary marine deposits in Buenos Aires province, Argentina. Marine Geology 128, 85-104.

Aguirre, M.L., Sirch, Y.N., Richiano, S., 2005. Late Quaternary molluscan assemblages from the coastal area of Bahía Bustamante (Patagonia, Argentina): Paleoecology and paleoenvironments. Journal of South American Earth Sciences Quaternary Paleontology and Biostratigraphy of southern South Africa 20, 13-32.

Aguirre, M.L., Richiano, S., Negro Sirch, Y., 2006. Palaeoenvironments and palaeoclimates of the Quaternary molluscan faunas from the coastal area of Bahía Vera-Camarones (Chubut, Patagonia). Palaeogeography, Palaeoclimatology, Palaeoecology 229, 251-286.

Aguirre, M.L., Richiano, S., Álvarez, M.F., Eastoe, C., 2009. Malacofauna Cuaternaria del litoral norte de Santa Cruz (Patagonia, Argentina). Geobios 42, 411-434.

Augustinus, P., 1989. Cheniers and chenier plains : a general introduction. Marine Geology 90, 219-229.

Barabas, M., Bach, A., Mudelsee, M., Mangini, A., 1992a. General properties of the paramagnetic center at $\mathrm{g}=2.0006$ in carbonates. Quaternary Science Reviews 11 $167-171$

Barabas, M., Mudelsee, M., Walther, R., Mangini, A., 1992b. Dose response and therma behaviour of the ESR signal at $\mathrm{g}=2.0006$ in carbonates. Quaternary Science Reviews 11, 173-179.

Barbosa, L.M., Bittencourt, A., Landim Dominguez, J.M., Martin, L., 1986. The Quaternary coastal deposits of the State of Alagoas : influence of relative sea-level changes. Quaternary of South America \& Antarctica Peninsula 4, 269-290.

Barker, P.F., 2001. Scotia Sea regional tectonic evolution: implications for mantle flow and palaeocirculation. Earth Science Reviews 55, 1-39.

Barreto, A.M.F., Bezerra, F.H.R., Suguio, K., Tatumi, S.H., Yee, M., Paiva, R.P., Munita, C.S 2002. Late Pleistocene marine terrace deposits in northeastern Brazil: sea-level change and tectonic implications. Palaeogeography, Palaeoclimatology, Palaeoecology 179, 57-69.

Bernat, M., Martin, L., Bittencourt, A., Vilas Boas, G., 1983. Datations Io-U du plus haut niveau marin du dernier interglaciaire sur la côte du Brésil : utilisation du 229Th comme traceur. Compte Rendu Académie des Sciences, Paris, Série II 296, 197-200.

Boyé, M., 1959. Données nouvelles sur les formations sédimentaires côtières de la Guyane Française, IFAT, Cayenne, p. 34.

Bujalesky, G., 1999. La costa de Tierra del Fuego, Argentina, Ushuaia, Centro Austral de Investigaciones Científicas (CONICET), p. 30.

Bujalesky, G., 2007. Coastal geomorphology and evolution of Tierra del Fuego (Southern Argentina). Geologica Acta 5, 337-362.

Bujalesky, G., Isla, F.I., 2006. Depósitos cuaternarios de la costa atlántica fueguina, entre los Cabos Peñas y Ewan. Revista de la Asociacion Geologica Argentina 61, 81-92.

Bull, W.B., 1985. Correlation of Flights of Global Marine Terraces: 15th Annual Geomorphology Symposium, pp. 129-152.

Caldenius, C., 1940. The Tehuelche or Patagonian Shingle-Formation. A Contribution to the Study of Its Origin. Geografiska Annaler 22, 160-181.

Cande, S.C., Leslie, R.B., 1986. Late Cenozoic Tectonics of the Southern Chile Trench. Journal of Geophysical Research-Solid Earth and Planets 91, 471-496.

CARP, 1989. Capítulo I. Aspectos Geológicos, Estudio para la evaluación de la contaminación en el Río de la Plata. Comisión Administradora del Río de la Plata Buenos Aires, pp. 1-72.

Chappell, J., 1974. Geology of coral terraces, Huon Peninsula, New Guinea: a study of Quaternary tectonic movements and sea-level changes. Geological Society of America Bulletin 85, 553-570.

Cionchi, J.L., 1987. Depositos marinos cuaternarios de Bahia Bustamante, Provincia del Chubut. Revista de la Asociacion Geologica Argentina 42, 61-72.

Cionchi, J.L., 1988. Geomorfologia de Bahia Bustamante y zonas adyacentes, Chubut. Revista de la Asociacion Geologica Argentina 43, 51-62.

Codignotto, J.O., 1983. Depositos elevados y/o de Acrecion Pleistoceno-Holoceno en la costa Fueguino-Patagonica.: Simposio Oscilaciones del nivel del mar durante el ultimo hemiciclo deglacial en la Argentina, pp. 12-26.

Codignotto, J.O., 1987. Cuaternario marino entre Tierra del Fuego y Buenos Aires. Revista de la Asociación Geológica Argentina 42, 208-212.

Codignotto, J.O., Aguirre, M.L., 1993. Coastal evolution, changes in sea level and molluscan fauna in northeastern Argentina during the Late Quaternary. Marine Geology 110, 163-175.

Codignotto, J.O., Marcomini, S.C., Santillana, S.N., 1988. Terrazas Marinas Entre Puerto Deseado Y Bahía Bustamante, Santa Cruz, Chubut. Revista de la Asociación Geológica Argentina 43, 43-50.

Codignotto, J.O., Kokot, R.R., Marcomini, S.C., 1992. Neotectonism and sea-level changes in the coastal zone of Argentina. Journal of Coastal Research 8, 125-133.

Cooper, F.J., Roberts, G.P., Underwood, C.J., 2007. A comparison of $10^{3}-10^{5}$ year uplift rates on the South Alkyonides Fault, central Greece: Holocene climate stability and the formation of coastal notches. Geophysical Research Letters 34, 1-6.
Coutand, I., Diraison, M., Cobbold, P.R., Gapais, D., Rossello, E.A., Miller, M., 1999. Structure and kinematics of a foothills transect, Lago Viedma, southern Andes $\left(49^{\circ} 30^{\prime}\right.$ S). Journal of South American Earth Sciences 12, 1-15.

Cunningham, W.D., Dalziel, I.W.D., Lee, T.-Y., Lawver, L.A., 1995. Southernmost South America-Antarctic Peninsula relative plate motions since $84 \mathrm{Ma}$ implications for the tectonic evolution of the Scotia Arc region. Journal of Geophysical ResearchSolid Earth and Planets 100, 8257-8266.

Darwin, C.R., 1842. The structure and distribution of coral reefs. Being the first part of the geology of the voyage of the Beagle, under the command of Capt. Fitzroy, R.N. during the years 1832 to 1836 . Smith Elder and Co., London. 214p.

Darwin, C.R., 1846. Geological observations on South America. Being the third part of the geology of the voyage of the Beagle, under the command of Capt. Fitzroy, R.N. during the years 1832 to 1836 . Smith Elder and Co., London. 279pp.

DeMets, C., Gordon, R.G., Argus, D.F., Stein, S., 1994. Effect of recent revisions to the geomagnetic reversal time scale on estimates of current plate motions. Geophysical Research Letters 21, 2191-2194.

d'Orbigny, A., 1834-1847, Voyage dans l'Amérique Méridionale, v. Tome V(3): Paris, 778 p.

Feruglio, E., 1933. I terrazi marini della Patagonia: Giornale di Geologia Annali Reale Museo geologico di Bologna, pp. 1-288.

Feruglio, E., 1950, Descripcion geologica de la Patagonia, v. T3: Buenos Aires, Direccion General de Y.P.F., $431 \mathrm{p}$.

Fucks, E., Aguirre, M., Deschamps, C.M., 2005. Late Quaternary continental and marine sediments of northeastern Buenos Aires province (Argentina): fossil content and paleoenvironmental interpretation. Journal of South American Earth Sciences Quaternary Paleontology and Biostratigraphy of Southern South Africa 20, 45-56.

González Bonorino, G., Bujalesky, G., Colombo, F., Ferrero, M., 1999. Holocene coastal paleoenvironments in Atlantic Patagonia, Argentina. Journal of South American Earth Sciences 12, 325-331.

Guilcher, A., 1974. Les «rasas» : un problème de morphologie littorale générale. Annales de Géographie 83, 1-33.

Guillaume, B., Martinod, J., Husson, L., Roddaz, M., Riquelme, R., 2009. Neogene uplift of central eastern Patagonia: dynamic response to active spreading ridge subduction? Tectonics 28.

Guivel, C.I., Lagabrielle, Y., Bourgois, J., Martin, H., Arnaud, N., Fourcade, S., Cotten, J., Maury, R., 2003. Very shallow melting of oceanic crust during spreading ridge subduction: origin of near-trench Quaternary volcanism at the Chile Triple Junction. Journal of Geophysical Research 108.

Gurnis, M., 1993. Phanerozoic marine inundation of continents driven by dynamic topography above subducting slabs. Nature 364, 589-593.

Hearty, P., Kindler, P., 1995. Sea-level highstand chronology from stable carbonate platforms (Bermuda and The Bahamas). Journal of Coastal Research 11, 675-689.

Hervé, F., Pankhurst, R.J., Fanning, M., Calderon, M., Yaxley, G.M., 2007. The South Patagonian batholith: 150 my of granite magmatism on a plate margin. Lithos 97 , 373-394.

Hoyt, J.H., 1969. Chenier versus barrier, genetic and stratigraphic distinction. American Association of Petroleum Geologist Bulletin 53, 299-306.

Hulton, N.R.J., Purves, R.S., McCulloch, R.D., Sugden, D.E., Bentley, M.J., 2002. The Last Glacial Maximum and deglaciation in southern South America. Quaternary Science Reviews 21, 233-241.

Husson, L., 2006. Dynamic topography above retreating subduction zones. Geology 34, 741-744.

Imbrie, J., Hays, J.D., Martinson, D.G., McIntyren, A., Mix, A.L., Morley, J.J., Pisias, N.G., Prell, W., Shackleton, N.J., 1984. The orbital theory of Pleistocene climate: support from revised chronology of the marine 180 record. In: Berger, A., et al. (Ed.), Milankovitch and Climate. Reidel, Dordrecht, Netherlands, pp. 269-305.

Isla, F.I., Bujalesky, G.G., 2000. Cannibalisation of Holocene gravel beach-ridge plains, northern Tierra del Fuego, Argentina. Marine Geology 170, 105-122.

Ivins, E.R., James, T.S., 2004. Bedrock response to Llanquihue Holocene and present-day glaciation in southernmost South America. Geophysical Research Letters 31.

James, N.P., Mountjoy, E.W., Omura, A., 1971. An early Wisconsin reef terrace at Barbados, West Indies, and its climatic implications. Geological Society of America Bulletin 82, 2011-2017.

Jardine, W.G., 1981. The determination of former shoreline positions in areas of large tidal range, with examples taken mainly from Scotland. Bulletin de l'Association française pour l'étude du quaternaire 18, 67-70.

Johnson, M.E., Libbey, L.K., 1997. Global review of upper Pleistocene (substage 5e) rocky shores : tectonic segregation, substrate variation, and biological diversity. Journal of Coastal Research 13, 297-307.

King, L.C., 1956. A geomorphological comparison between Eastern Brazil and Africa (Central and Southern). Quarterly Journal of the Geological Society 112, 445-474.

Klemann, V., Ivins, E.R., Martinec, Z.k., Wolf, D., 2007. Models of active glacial isostasy roofing warm subduction: case of the South Patagonian Ice Field. Journal of Geophysical Research 112.

Kukla, G.J., Bender, M.L., de Beaulieu, J.-L., Bond, G., Broecker, W.S., Cleveringa, P., Gavin, J.E., Herbert, T.D., Imbrie, J., Jouzel, J., Keigwin, L.D., Knudsen, K.-L., McManus, J.F., Merkt, J., Muhs, D.R., Müller, H., Poore, R.Z., Porter, S.C., Seret, G., Shackleton, N.J., Turner, C., Tzedakis, P.C., Winograd, I.J., 2002. Last interglacial climates. Quaternary Research 58, 2-13.

Lagabrielle, Y., Suguio, K., Rossello, E.A., Herail, G., Martinod, J., Regnier, M., de la Cruz, R., 2004. Neogene to Quaternary tectonic evolution of the Patagonian Andes at the latitude of the Chile Triple Junction. Tectonophysics 385, 211-241.

Lagabrielle, Y., Suárez, M., Malavieille, J., Morata, D., Espinoza, F., Maury, R.C., Scalabrino, B., Barbero, L., Cruz, R.d.l., Rossello, E., Bellon, H., 2007. Pliocene extensional tectonics in the Eastern Central Patagonian Cordillera: geochronological constraints and new field evidence. Terra Nova 19, 413-424. 
Lajoie, K.R., 1986. Coastal tectonics. In: Press, N.A. (Ed.), Active Tectonic. National Academic Press, Washington D.C., pp. 95-124.

Leroy, M., Dauteuil, O., Cobbold, P., 2004. Compression of passive margins: controls from oceanic lithosphere rheology. Geophysical Journal International 159, 400-411.

Ludwig, K.R., 2003. Isoplot 3.00 manual, Berkeley Geochronology Center Special Publication No. 4.

Maeda, Y., Siringan, F., Omura, A., Berdin, R., Hosono, Y., Atsumi, S., Nakamura, T., 2004. Higher-than-present Holocene mean sea levels in Ilocos, Palawan and Samar, Philippines. Quaternary International 115-116, 15-26.

Martin, L., Suguio, K., 1976. Etude préliminaire du quaternaire marin : comparaison du littoral de Sao Paulo et de Salvador de Bahia (Brésil): Cahier O.R.S.T.O.M., série Géologie, v. VIII, pp. 33-47.

Martin, L., Suguio, K., Flexor, J.M., 1979. Le Quaternaire marin du littoral Brésilien entre Cananeia (SP) and Barra de Guaratiba (RJ). International Symposium on Coastal evolution in the Quaternary 231-296.

Martin, L., Suguio, K., Flexor, J.-M., 1988. Hauts niveaux marins Pleistocenes du littoral bresilien. Palaeogeography, Palaeoclimatology, Palaeoecology Quaternary Coastal Changes 68, 231-239.

Martin, L., Suguio, K., Flexor, J.M., Dominguez, J.M.L., Bittencourt, A.C.S.P., 1996 Quaternary sea-level history along the central Part of the Brazilian Coast. Variations in coastal dynamics and their consequences on coastal plain construction. Anais da Academia Brasileira de Ciencias 68, 304-354.

Martínez, S., Ubilla, M., Verde, M., Perea, D., Rojas, A., Guérèquiz, R., Piñeiro, G., 2001. Paleoecology and geochronology of Uruguayan coastal marine Pleistocene deposits. Quaternary Research 55, 246-254.

Meldahl, K.H., 1995. Pleistocene shoreline ridges from tide-dominated and wavedominated coasts: northern Gulf of California and western Baja California, Mexico. Marine Geology 123, 61-72.

Mercer, J.H., 1976. Glacial history of Southernmost South-America. Quaternary Research 6, 125-166.

Mitrovica, J.X., Beaumont, C., Jarvis, G.T., 1989. Tilting of continental interiors by the dynamical effects of subduction. Tectonics 8, 1079-1094.

Monti, J.A., 2002. Evolucion de las investigaciones geomorfologicas sobre los procesos marinos costeros registrados en el Cuaternario tardio (Holoceno) en la Patagonia. Parrafos Geograficos I, 206-222.

Ortiz-Troncoso, O.R., 1979. Punta Santa Ana et Bahía Buena : deux gisements sur une ancienne ligne de rivage dans le détroit de Magellan. Journal de la Société des Américanistes 66, 133-204.

Otvos, E.G., 1981. Tectonic lineaments of Pliocene and Quaternary shorelines, northeast Gulf Coast. Geology 9, 398-404

Otvos, E.G., 2000. Beach ridges-definitions and significance. Geomorphology 32, 83-108.

Otvos, E.G., Price, W., 1979. Problems of chenier genesis and terminology-an overview. Marine Geology 31, 251-263.

Pedoja, K., Bourgeois, J., Pinegina, T., Higman, B., 2006a. Does Kamchatka belong to North America? An extruding Okhotsk block suggested by coastal neotectonics of the Ozernoi Peninsula, Kamchatka, Russia. Geology 34, 353-356.

Pedoja, K., Dumont, J.F., Lamothe, M., Ortlieb, L., Collot, J.-Y., Ghaleb, B., Auclair, M., Alvarez, V., Labrousse, B., 2006b. Plio-Quaternary uplift of the Manta Peninsula and La Plata Island and the subduction of the Carnegie Ridge, central coast of Ecuador. Journal of South American Earth Sciences 22, 1-21.

Pedoja, K., Regard, V., Husson, L., Martinod, J., Iglesias, M., 2008a. Why is the passive margin of Argentinean Patagonia uplifting? An insight by marine terrace and tidal notches sequences: Seventh International Symposium on Andean Geodynamics (ISAG).

Pedoja, K., Shen, J.W., Kershaw, S., Tang, C., 2008b. Coastal Quaternary morphologies on the northern coast of the South China Sea, China, and their implications for current tectonic models: a review and preliminary study. Marine Geology 255, 103-117.

Pirazzoli, P.A., 1996. Sea-Level Changes: The Last 20,000 Years. Wiley. 224pp.

Polenz, M., Kelsey, H.M., 1999. Development of a Late Quaternary marine terraced landscape during on-going tectonic contraction, Crescent City Coastal Plain, California. Quaternary Research 52, 217-228.

Rabassa, J., Gordillo, S., Ocampo, C., Rivas Hurtado, P., 2008. The southernmost evidence for an interglacial transgression (Sangamon?) in South America. First record of upraised Pleistocene marine deposits in Isla Navarino (Beagle Channel, Southern Chile). Geologica Acta 6, 251-258.

Radtke, U., 1989. Marine terrassen und korallenriffe. Das problem der Quartären meeresspiegelschwankungen erläntert an fallstudien aus Chile, Argentinien und Barbados. Düsseldorfer Geographische Schriften 27, 245.

Radtke, U., Schellmann, G., 1996. Comment on: Aguirre, M.L. and Whatley, R.C. (1995). Late quaternary marginal marine deposits and palaeoenvironments from northeastern Buenos Aires province, Argentina: a review. Quaternary science reviews, 14, 223-254. Quaternary Science Reviews 15, 1061-1062.

Ramos, V.A., 1981. Descripcion geologico-economica de la hoja 55 a Sierra de Sangra, provincia de Santa Cruz: Servicio Geologico Nacional de Argentina.

Ramos, V.A., 1989. Andean foothills structures in Northern Magallanes Basin, Argentina. American Association of Petroleum Geologists Bulletin 73, 887-903.

Ramos, V.A., 1996. Evolucion tectonica de la plataforma continental. In: Ramos, V.A. Turic, M.A. (Eds.), Geologia y recursos naturales de la plataforma continental argentina, Asociacion Geologica Argentina e Instituto Argentino del Petroleo, pp. $385-404$.

Ramos, V.A., 2002. Evolucion tectonica. In: Haller, M.J. (Ed.), Geologia y Recursos Naturales de Santa Cruz, pp. 165-174.

Ramos, V.A., Kay, S.M., 1992. Southern Patagonian plateau basalts and deformationbackarc testimony of ridge collisions. Tectonophysics 205, 261-282.
Rapalini, A.E., Herve, F., Ramos, V.A., Singer, S.E., 2001. Paleomagnetic evidence for a very large counterclockwise rotation of the Madre de Dios Archipelago, southern Chile. Earth and Planetary Science Letters 184, 471-487.

Rostami, K., Peltier, W.R., Mangini, A., 2000. Quaternary marine terraces, sea-level changes and uplift history of Patagonia, Argentina: comparisons with predictions of the ICE-4G (VM2) model of the global process of glacial isostatic adjustment. Quaternary Science Reviews 19, 1495-1525.

Russo, R., Silver, P.G., 1996. Cordillera Formation, Mantle Dynamics, and the Wilson Cycle. Geology 24, 511-514.

Rutter, N., Schnack, E.J., Rio, J.d., Fasano, J.L., Isla, F.I., Radtke, U., 1989. Correlation and dating of Quaternary littoral zones along the Patagonian coast, Argentina. Quaternary Science Reviews 8, 213-234.

Rutter, N., Radtke, U., Schnack, E.J., 1990. Comparison of ESR and amino acid data in correlating and dating Quaternary shorelines along the Patagonian coast, Argentina. Journal of Coastal Research 6, 391-411.

Saillard, M., Hall, S.R., Audin, L., Farber, D.L., Hérail, G., Martinod, J., Regard, V., Finkel, R.C., Bondoux, F., 2009. Non-steady long-term uplift rates and Pleistocene marine terrace development along the Andean margin of Chile $\left(31^{\circ} \mathrm{S}\right)$ inferred from $10 \mathrm{Be}$ dating. Earth and Planetary Science Letters 277, 50-63.

Sanjaume, E., Tolgensbakk, J., 2009. Beach ridges from the Varanger Peninsula (Arctic Norwegian coast): characteristics and significance. Geomorphology Coastal Geomorphology 104, 82-92.

Sauer, D., Schellmann, G., Stahr, K., 2007. A soil chronosequence in the semi-arid environment of Patagonia (Argentina): CATENA Rates and Time Scales of Pedogenic Processes in Natural and Man-Affected Soil Systems, v. 71, pp. 382-393.

Schellmann, G., 1998. Coastal development in Southern South America (Patagonia and Chile) since the Younger Middle Pleistocene-sea-level changes and neotectonics. In: Kelletat, D. (Ed.), German Geographical Coastal Research: The Last Decade: Tübingen, Institute for Scientific Co-operation Tübingen. IGU Sonderband, pp. 289-304.

Schellmann, G., Radtke, U., 1997. Electron spin resonance (ESR) techniques applied to mollusc shells from South America (Chile, Argentina) and implications for palaeo sea-level curve. Quaternary Science Reviews 16, 465-475.

Schellmann, G., Radtke, U., 2000. ESR dating stratigraphically well-constrained marine terraces along the Patagonian Atlantic coast (Argentina). Quaternary International 68-71, 261-273.

Schellmann, G., Radtke, U., 2003. Coastal terraces and Holocene sea-level changes along the Patagonian Atlantic Coast. Journal of Coastal Research 983-996.

Schellmann, G., Radtke, U., 2004. A revised morpho- and chronostratigraphy of the Late and Middle Pleistocene coral reef terraces on Southern Barbados (West Indies). Earth Science Reviews 64, 157-187.

Siddal, M., Chappell, J., Potter, E.-K., 2006. Eustatic sea level during past interglacials. In: Sirocko, F., Claussen, M., Sanchez Goñi, M.F., Litt, T. (Eds.), The Climate of Past Interglacials. Elsevier, Amsterdam, pp. 75-92.

Silver, P.G., Russo, R., Lithgow-Bertelloni, 1998. Coupling of South American and African plate motion and plate deformation. Science 279.

Stirling, C.H., Esat, T.M., Lambeck, K., McCulloch, M.T., 1998. Timing and duration of the Last Interglacial: evidence for a restricted interval of widespread coral reef growth. Earth and Planetary Science Letters 160, 745-762.

Tanner, W.F., 1995a. Origin of beach ridges and swales. Marine Geology 129, 149-161. Tanner, W.F., 1995b. Beach ridges. Marine Geology 129, 147.

Tassara, A., Swai, C., Hackney, R., Kirby, J., 2007. Elastic thickness structure of South America estimated using wavelets and satellite-derived gravity data. Earth and Planetary Science Letters 253 (1-2), 17-36.

Tatumi, S.H., Kowata, E.A., Gozzi, G., Kassab, L.R.P., Suguio, K., Barreto, A.M.F., Bezerra F.H.R., 2003. Optical dating results of beachrock, eolic dunes and sediments applied to sea-level changes study: Journal of Luminescence Proceedings of the 2002 International Conference on Luminescence and Optical Spectroscopy of Condensed Matter, v. 102-103, pp. 562-565.

Thomas, C., Livermore, R., Pollitz, F., 2003. Motion of the Scotia Sea plates. Geophysical Journal International 155, 789-804.

Tomazelli, L.J., Dillenburg, S.R., 2007. Sedimentary facies and stratigraphy of a last interglacial coastal barrier in south Brazil. Marine Geology 244, 33-45.

Ton-That, R., Singer, B., Mörner, N.-A., Rabassa, J., 1999. Datación de lavas basálticas por $40 \mathrm{Ar} / 39 \mathrm{Ar}$ y geologia glacial de la región del lago Buenos Aires, provincia de Santa Cruz, Argentina. Revista de la Asociacion Geologica Argentina 54, 333-352.

Torsvik, T.H., Rousse, S., Labails, C., Smethurst, M.A., 2009. A new scheme for the opening of the South Atlantic Ocean and the dissection of an Aptian salt basin. Geophysical Journal International 177, 1315-1333.

Tricart, J., Galliposo, M., Goso, L., 1972. Aperçu sur le Quaternaire des abords du rio de la Plata (Argentine et Uruguay): bulletin de l'Association Française pour l'Etude du Quaternaire 9, 3-19.

Turner, K.J., Fogwill, C.J., McCulloch, R.D., Sugden, D.E., 2005. Deglaciation of the eastern flank of the North Patagonian Icefield and associated continental-scale lake diversions. Geografiska Annaler Series a-Physical Geography 87, 363-374.

Vilas, F., Arche, A., Ferrero, M., Isla, F., 1999. Subantarctic macrotidal flats, cheniers and beaches in San Sebastian Bay, Tierra Del Fuego, Argentina. Marine Geology 160 301-326.

Wright, L.R., 1970. Variation in the level of cliff-shore platform junction along the south coast of Great Britain. Marine Geology 9, 347-353.

Zazo, C., 1999. Interglacial sea levels. Quaternary International 55, 101-113.

Zeller, E.J., Levy, P.W., Mattern, P.L., 1967. Geological dating by electron spin resonance, Symposium on Radioactive Dating and Low Level Counting, I.A.E.A., Wien, p. 531. 